\title{
Emerging Roles of Small GTPases in Islet $\beta$-Cell Function
}

\author{
Rajakrishnan Veluthakal * and Debbie C. Thurmond *
}

Department of Molecular and Cellular Endocrinology, Arthur Riggs Diabetes \& Metabolism Research Institute, City of Hope Beckman Research Institute, Duarte, CA 91010, USA

* Correspondence: rveluthakal@coh.org (R.V.); dthurmond@coh.org (D.C.T.); Tel.: +1-626-256-4673 (R.V.); +1-626-218-0190 (D.C.T.)

Citation: Veluthakal, R.; Thurmond, D.C. Emerging Roles of Small GTPases in Islet $\beta$-Cell Function. Cells 2021, 10, 1503. https://doi.org/ 10.3390/cells10061503

Academic Editors: Igor Weber and Vedrana Filić

Received: 27 April 2021

Accepted: 8 June 2021

Published: 15 June 2021

Publisher's Note: MDPI stays neutral with regard to jurisdictional claims in published maps and institutional affiliations.

Copyright: (c) 2021 by the authors. Licensee MDPI, Basel, Switzerland. This article is an open access article distributed under the terms and conditions of the Creative Commons Attribution (CC BY) license (https:// creativecommons.org/licenses/by/ $4.0 /)$.
Abstract: Several small guanosine triphosphatases (GTPases) from the Ras protein superfamily regulate glucose-stimulated insulin secretion in the pancreatic islet $\beta$-cell. The Rho family GTPases Cdc42 and Rac1 are primarily involved in relaying key signals in several cellular functions, including vesicle trafficking, plasma membrane homeostasis, and cytoskeletal dynamics. They orchestrate specific changes at each spatiotemporal region within the $\beta$-cell by coordinating with signal transducers, guanine nucleotide exchange factors (GEFs), GTPase-activating factors (GAPs), and their effectors. The Arf family of small GTPases is involved in vesicular trafficking (exocytosis and endocytosis) and actin cytoskeletal dynamics. Rab-GTPases regulate pre-exocytotic and late endocytic membrane trafficking events in $\beta$-cells. Several additional functions for small GTPases include regulating transcription factor activity and mitochondrial dynamics. Importantly, defects in several of these GTPases have been found associated with type 2 diabetes (T2D) etiology. The purpose of this review is to systematically denote the identities and molecular mechanistic steps in the glucose-stimulated insulin secretion pathway that leads to the normal release of insulin. We will also note newly identified defects in these GTPases and their corresponding regulatory factors (e.g., GDP dissociation inhibitors (GDIs), GEFs, and GAPs) in the pancreatic $\beta$-cells, which contribute to the dysregulation of metabolism and the development of T2D.

Keywords: small GTPase; actin remodeling; $\beta$-cell; guanine nucleotide exchange factors; readily releasable pool; cytoskeleton; diabetes; exocytosis; insulin

\section{Introduction}

Pancreatic islet $\beta$-cells release the hormone insulin in response to elevated blood glucose concentrations, especially after meals, via a process called glucose-stimulated insulin secretion (GSIS) [1,2]. Insulin maintains whole-body glucose homeostasis by facilitating glucose uptake in primary tissues, such as skeletal muscle and adipose tissue, and reducing gluconeogenesis in the liver [3]. Upon sensing glucose, the $\beta$-cells take up glucose via glucose transporters (GLUT1 in humans and GLUT2 in rodents) [4] and initiate glucose metabolism [5-8]. The metabolism of glucose induces a plethora of signaling events, which change the ATP / ADP ratio, trigger the closure of ATP-sensitive potassium channels, and depolarize the plasma membrane (PM). These actions open PM-localized voltage-dependent $\mathrm{Ca}^{2+}$ channels (VDCCs), and the influx of $\mathrm{Ca}^{2+}$ from the extracellular space elicits the rapid release of insulin from pre-packaged insulin granules within the $\beta$-cell (reviewed elsewhere [9]) (Figure 1). The insulin secretory process is biphasic [10-12]; the first phase, lasting $10 \mathrm{~min}$, is associated with rapid and robust insulin secretion, whereas the second phase is associated with a less robust level of secretion but continues as long as elevated glucose levels persist [13]. The Rho, Arf, and Rab families of small GTPases are required for this biphasic pattern of insulin release from the $\beta$-cell, overseeing the actin cytoskeletal remodeling, which is required for mobilizing the insulin granules to their docking/fusion sites at the inner PM for regulated release of insulin into the circulation [14,15]. 


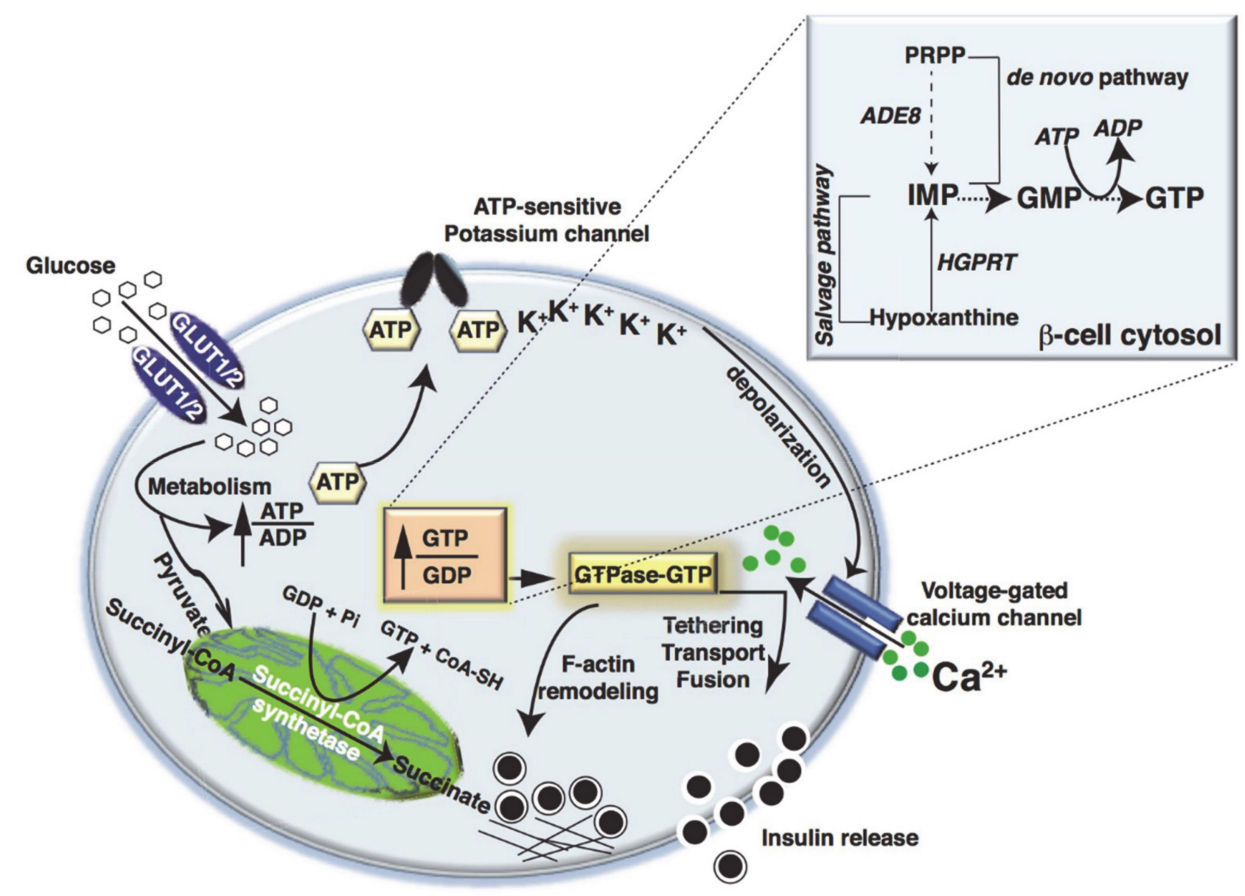

Figure 1. Glucose-stimulated insulin secretion. Glucose is taken up by $\beta$-cells via the GLUT1 (human) or GLUT2 (rodent) transporter and undergoes metabolism via mitochondrial oxidation, leading to the generation of ATP. When the ATP/ADP ratio increases, the $\mathrm{K}^{\text {ATP }}$ channel closes, and membrane depolarization ensues. Subsequently, voltage-gated calcium channels open, and $\mathrm{Ca}^{2+}$ enters to drive insulin granule exocytosis. Meanwhile, in the mitochondria, converion of Succinyl-CoA in the tricarboxylic acid cycle by Succinyl-CoA synthetase causes the formation of mitochondrial GTP. In addition, in the soluble compartment, GTP can be formed from a salvage pathway using hypoxanthine as a substrate. The enzyme hypoxanthine-guanine phosphoribosyltransferase (HGPRT) catalyzes the conversion of hypoxanthine to inosine monophosphate (IMP) and guanine to guanosine monophosphate to GTP. GTP can be also formed by an alternate de novo synthesis pathway, using phosphoribosyl pyrophosphate (PRPP), by the enzyme phosphoribosylglycinamide formyltransferase (ADE8), which then increases the GTP/GDP ratio. This causes differential regulation of GTPases and enhances insulin release.

\section{Metabolic Fate of Glucose in Islet $\beta$-Cells}

Glucose is converted to pyruvate in the cytosol via glycolysis. However, the levels of cytosolic lactate dehydrogenase are lower in $\beta$-cells than in other cell types, and this favors $\beta$-cells to continue glycolysis using mitochondrial pyruvate uptake and metabolism $[16,17]$. This glucose metabolism increases the GTP/GDP ratio in a concentration-dependent manner, and insulin secretion is inversely proportional to GDP levels and directly proportional to GTP/GDP ratios [18-20]. Several studies have provided evidence for a particular role of mitochondrial GTP (mtGTP) in GSIS [21-23]. For example, the tricarboxylic acid (TCA) cycle enzyme succinyl-CoA synthetase (SCS) catalyzes the substrate-level synthesis of mtGTP and mitochondrial ATP (mtATP) when pyruvate is catabolized in the TCA cycle [22]. Mitochondrial ATP (mtATP) is produced largely by oxidative phosphorylation and is dependent on the mitochondrial membrane potential $(\Delta \Psi)$. Only a fraction of ATP is directly formed from TCA cycle by the ATP dependent succinyl-CoA synthetase (SCS-ATP). Therefore, changes in the mitochondrial matrix ATP/ADP ratio are limited due to the rapid export of mtATP to the cytosol via the ATP/ADP transporter (AAT). In contrast, mtGTP is only metabolically generated by the GTP-specific isoform of SCS (SCS-GTP). As a result, mtGTP is trapped in the matrix, yielding increases in GTP/GDP that are much more substantial than mtATP [21,22]. Each molecule of glucose metabolized in the $\beta$-cell produces approximately one mtGTP, making mtGTP a potentially important fuel signal. In 
rat islets and the rat clonal $\beta$-cell line INS-1 832/13, RNAi suppression of SCS dramatically reduced mtGTP levels and caused a 50\% reduction in GSIS [22]. These data suggest a role for mtGTP in governing GSIS via modulation of mitochondrial metabolism, invoking changes in the mitochondrial $\mathrm{Ca}^{2+}$ levels.

Conversely, some reports have indicated a small increase in total GTP levels, both in the smaller mtGTP pool and the larger cytosolic GTP pools [18-20]. Two pathways are involved in the synthesis of GTP. First, in the salvage pathway, the purine base hypoxanthine is recycled by hypoxanthine-guanine phosphoribosyltransferase (HGPRT) to generate inosine monophosphate (IMP), which serves as a precursor for GMP from which GTP is synthesized. Secondly in the de novo pathway, Phosphoribosyl-glycinamide transformylase (ADE8) catalyzes a step in the de novo purine nucleotide biosynthetic pathway. The purine ring is sequentially constructed from small molecule donors on a ribose 5phosphate backbone provided by 5-phosphoribosyl-1-pyrophosphate (PRPP) to form the first purine product, IMP. IMP is channeled to form GMP and, subsequently, GTP [24] (Figure 1). Although one molecule of mtGTP is produced by the GTP-specific isoform of SCS per molecule of glucose oxidized, due to slow cytoplasmic exchange, mtGTP is trapped in the matrix; therefore, the increase in GTP/GDP is substantial [25,26]. This regulatory mechanism differs from the regulation of the mitochondrial ATP/ADP ratio, which is limited by the rapid export of mtATP to the cytosol via the ATP/ADP transporter (AAT). Therefore, although the increase in GTP/GDP reflects $\beta$-cell TCA cycle activity, the mtATP production rates do not necessarily correlate with the rate of glucose oxidation. The mitochondrial isoform of phosphoenolpyruvate carboxykinase (PEPCK-M) converts oxaloacetate to phosphoenolpyruvate (PEP), driving the co-transport of mtGTP and PEP into the cytosol via the citrate isocitrate carrier (CIC) [27]. In the cytosol, increased mtGTP enhances insulin secretion by increasing the number and/or size of insulin granules, and importantly, promotes the localization of insulin laden granules to the inner surface of the PM, staging them for subsequent release [23]. While mitochondrial GTP may impart resilience to $\beta$-cells exposed to glucolipotoxicity-induced metabolic stress [28], the extent to which this can prevent $\beta$-cell dysfunction, and progression toward diabetes, remains to be evaluated.

\section{Metabolic Dysfunction and Small GTPase Signaling in Islet $\beta$-Cells}

According to the International Diabetes Federation, in the year 2019, approximately 463 million adults (20-79 years of age) were living with diabetes, and it is estimated that by the year 2045, this will rise to 700 million. One in five of the people who are above 65 years old had diabetes, and one in two (232 million) people with diabetes was undiagnosed [29]. $\beta$-cell dysfunction contributes toward the etiology of type 2 diabetes (T2D) $[30,31]$. Undeniably, GSIS from T2D human islets is significantly reduced by $\sim 60 \%$ when compared with nondiabetics. Several key factors such as obesity (body-mass index $(\mathrm{BMI}) \geq 30 \mathrm{~kg} / \mathrm{m}^{2}$ ) and associated metabolic abnormalities, sedentary lifestyle, genetic, and environmental factors all contribute towards the development of T2D [32-36]. Both the first and second phases of insulin release are disturbed in T2D. A recent study demonstrated that in T2D human islets, there is a significant reduction in docked granules. Proteins associated with granule docking are downregulated in T2D, and their restoration improves granule docking [37]. There are several factors that are involved in the activation of GTPases that are dysfunctional in pancreatic $\beta$-cells from T2D individuals.

Type 1 diabetes (T1D) etiology is also now thought to begin with $\beta$-cell dysfunction, progressing to $\beta$-cell demise as a result of autoimmune attack. In the majority of patients (70-90\%), the loss of $\beta$-cells is the consequence of T1D-related autoimmunity (with concomitant increase in the formation of T1D-associated autoantibodies). In a smaller subset of patients, no immune responses or autoantibodies are detected, and the cause of $\beta$-cell destruction is unknown (idiopathic T1D). This type has a strong genetic component [38]. Pathological hyper- or hypo-activation of key GTPase impairs $\beta$-cell function, especially under peripheral insulin resistance-induced stress (T2D) and oxidative stress due to pro- 
inflammatory cytokines (T1D). As such, targeting aspects of these signaling pathways may hold therapeutic potential for preventing $\beta$-cell failure as a means to halt the progression of T2D and T1D. (Please see the following section below).

\section{Small Monomeric GTPases}

To date, 167 small GTPases have been identified in humans [39,40]. The GTP binding domain of these small GTPases is subdivided into five relatively conserved motifs: G1-G5 (Figure 2). The G1 motif, located between the B1 strand and the A1 helix, is responsible for binding the $\alpha$ and $\beta$ phosphate of GTP or GDP. The G2 loop connects the A1 helix and the $\mathrm{B} 2$ strand, and contains a conserved threonine residue responsible for $\mathrm{Mg}^{2+}$ binding. The G3 motif (II) is a $\gamma$-phosphate binding region. The G4 motif (III) contains lysine and aspartic acid residues which interact directly with the guanine nucleotide. Finally, the G5 motif (IV) makes indirect associations with the guanine nucleotide [41]. The GTPases also share conserved sequences [42] at the G-box: G1, GXXXXGKS/T; G2, T; G3, DXXGQ/H/T; G4, T/NKXD; and G5, C/SAK/L/T [43]. The small GTPases can be divided into five families according to sequence similarity and function; Ras, Rho, Rab, Arf, and Ran [44]. Members of the Ras family are considered signaling hubs that modulate effector molecules to translate extracellular cues into active processes, such as secretion, cell proliferation, differentiation, morphology, and apoptosis [45].

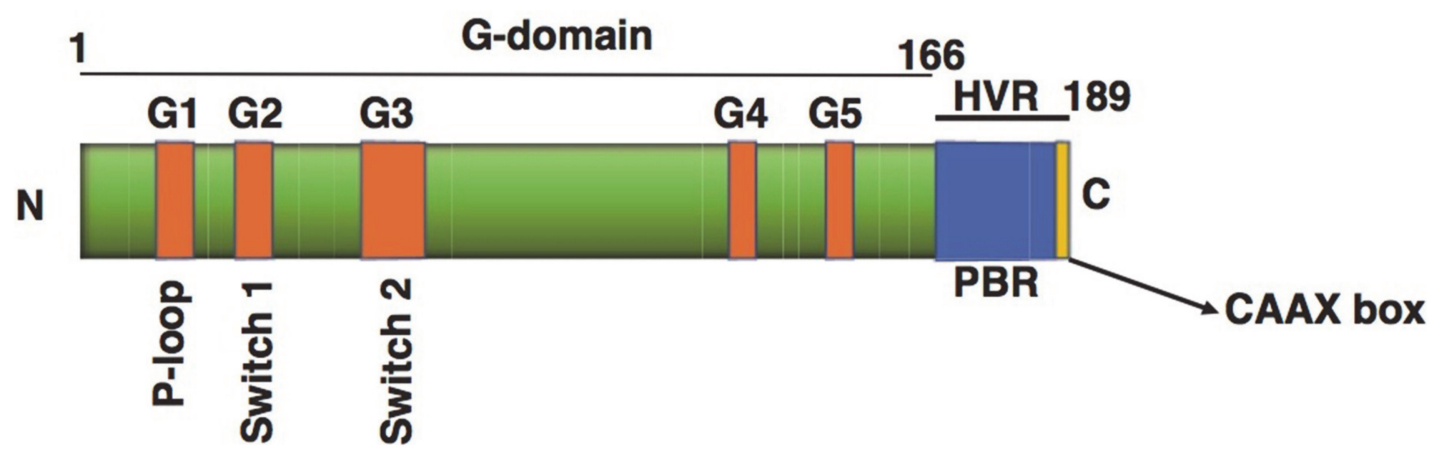

Figure 2. Structures of small GTPases. G boxes in the G domain (amino acids 1-166) are highlighted with orange boxes. The hypervariable (HVR) region, including a polybasic region (PBR) and a CAAX motif (166-189), is also highlighted. The CAAX box is the location in which post-translational modifications occur. The $G$ domain consists of a six-stranded $\beta$-sheet and five $\alpha$-helices, and has conserved sequence motifs G1 to G5. The G1 motif is also called the P-loop and is found in many nucleotide binding proteins, where it recognizes the $\beta$-phosphate and a $\mathrm{Mg}^{+}$ion of target nucleotides. The G2 motif (Switch 1) (Thr) makes contact with the $\gamma$-phosphate and the $\mathrm{Mg}^{2+}$ ion. The G3 motif (Switch 2) is responsible for GTP hydrolysis. The G4 and G5 motifs make specific contact with the guanine base to distinguish guanine from other nucleotides, Toma-Fukai et al., 2019 [46].

Islet $\beta$-cells express the Rho family of small GTPases which includes RhoA, RhoB, Rac1, and Cdc42 [47-57]. The Rab family of small GTPases includes Rab27a, Rab3a, Rab2a, and Rab37, which regulate insulin granule formation, movement, fusion, and trafficking [58,59]. The Arf family of small GTPases includes Arf6, which is also implicated in insulin granule trafficking [60,61] (Table 1). Ran is the only member of the Ran family and is involved in nuclear transport [62]. 
Table 1. Location and function of GTPases in the islet $\beta$-cell.

\begin{tabular}{|c|c|c|c|}
\hline GTPases in $\beta$-Cells & Location & Function & References \\
\hline Rac1 & $\begin{array}{l}\text { Cytosol (GDP-loaded), } \\
\text { PM (GTP-loaded) }\end{array}$ & $\begin{array}{l}\text { Cytoskeletal } \\
\text { rearrangement }\end{array}$ & {$[63,64]$} \\
\hline Cdc42 & $\begin{array}{c}\text { Cytosol/Insulin-containing } \\
\text { secretory granules } \\
\text { (GDP-loaded), PM } \\
\text { (GTP-loaded) }\end{array}$ & $\begin{array}{l}\text { Cytoskeletal } \\
\text { rearrangement/ } \\
\text { Vesicle fusion }\end{array}$ & {$[47-49,65,66]$} \\
\hline Arf6 & $\begin{array}{c}\text { Cytosol (GDP loaded), PM } \\
\text { (GTP loaded) }\end{array}$ & Vesicle fusion & {$[50]$} \\
\hline Rab27a & $\begin{array}{c}\text { Insulin-containing secretory } \\
\text { granules (GDP and } \\
\text { GTP loaded) }\end{array}$ & Docking/priming & [67] \\
\hline Rab37 & $\begin{array}{c}\text { Cytosol (GDP loaded) } \\
\text { Insulin-containing secretory } \\
\text { granules (GTP loaded) }\end{array}$ & Docking/priming & [68] \\
\hline Rab2a & $\begin{array}{l}\text { Cytosol (GDP loaded) } \\
\text { Perinuclear immature } \\
\text { granules (GTP loaded) }\end{array}$ & Docking/priming & [69] \\
\hline Rab3a & $\begin{array}{c}\text { Cytosol (GDP loaded) } \\
\text { Insulin-containing secretory } \\
\text { granules (GTP loaded) }\end{array}$ & Docking/priming & [70] \\
\hline Rap1 & $\begin{array}{c}\text { Colocalized with insulin } \\
\text { granules (GDP loaded), PM } \\
\text { (GTP loaded) }\end{array}$ & Docking/priming & [71] \\
\hline
\end{tabular}

PM, plasma membrane.

\subsection{Small GTPase Regulation in $\beta$-Cells}

GTPases are called molecular switches due to their regulated GDP/GTP exchange activity that evokes, or "switches on", key signaling events in response to select stimuli (Figure 3). GTPases display high-affinity binding for GDP in the inactive state and are activated when bound to GTP. GTPases possess low intrinsic GTP hydrolysis and GDP/GTP exchange activities; the exchange of GDP/GTP is overseen by two classes of regulatory proteins. First, guanine nucleotide exchange factors (GEFs) facilitate the exchange of GDP for GTP [72]. Additionally, GTPase-activating proteins (GAPs) increase the intrinsic GTPase activity to stimulate the formation of the inactive GTPase-GDP [73]. GTPases within a family share diverse GAPs and GEFs. Although GTPases in different families depend on structurally distinct GAPs and GEFs, the mechanism by which they promote GTPase cycles remains the same. The GTP and GDP-bound states of GTPases have similar conformations, albeit with notable differences in the switch I (e.g., Ras amino acid residues 30-38) and switch II (amino acid residues 59-67) regions. Furthermore, GTPases in their GTP-bound active state possess a high affinity toward effector proteins [74,75]. The activity status of the GTPase is "sensed" by either the regulatory or the effector proteins via the conformational changes in the switch I and II domains. 


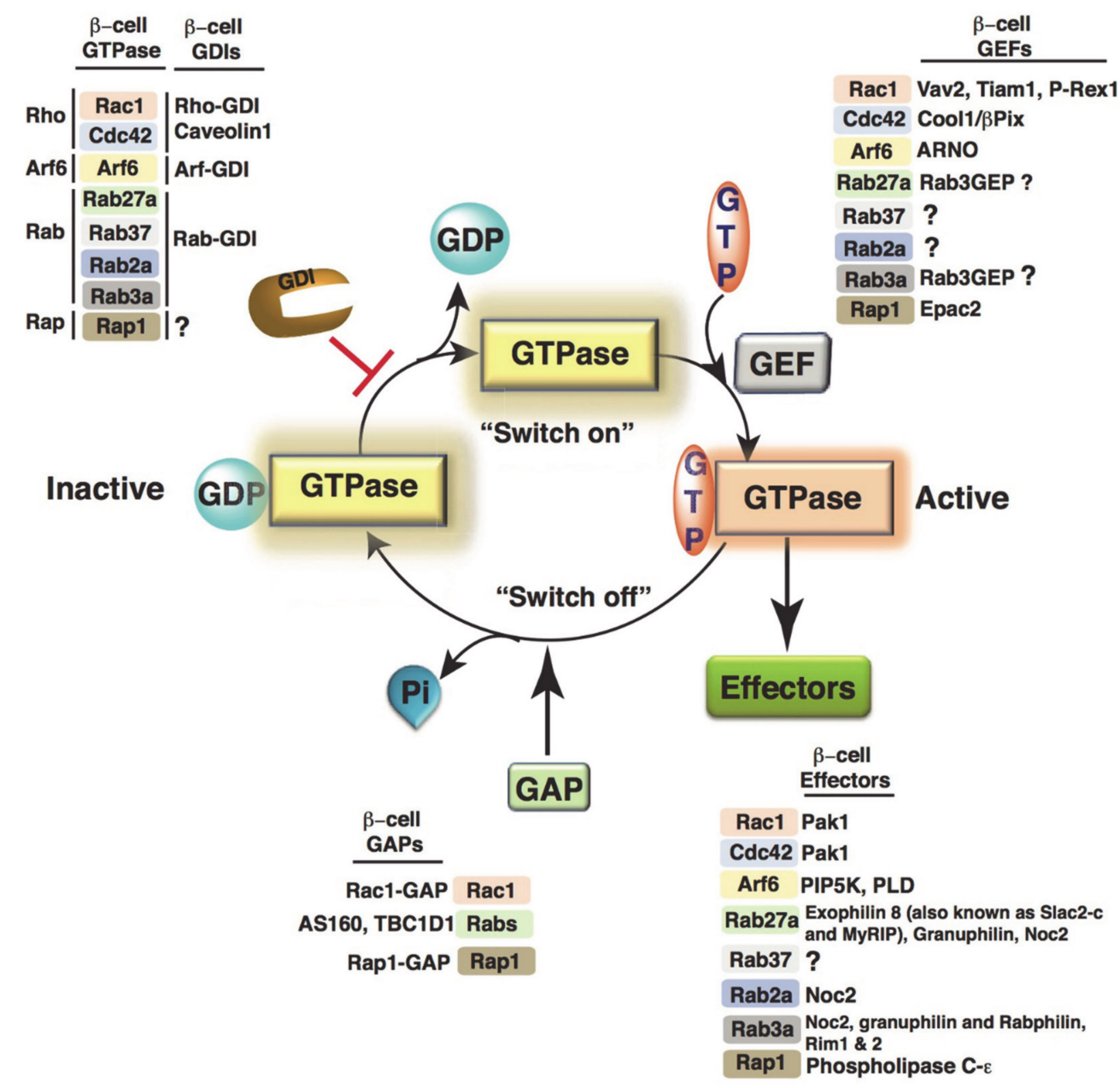

Figure 3. Molecular switch mechanism of GTPases. In resting cells, GTPases are bound to an inhibitory protein GDP dissociation inhibitor (GDI) in an inactive GDP-bound form. Upon stimulation, guanine nucleotide exchange factors (GEFs) facilitate the conversion of inactive GTPases to the active GTP-bound form. The active GTPase then interacts with the effector proteins to propagate the downstream signals. GTPase-activating proteins (GAPs) stimulate GTP hydrolysis from the active to inactive GTPase. The individual GEFs, GAPs, and GDIs relevant to islet $\beta$-cell signaling are listed with each GTPase.

\subsection{Post-Translational Modification of Small GTPases in $\beta$-Cells}

The small GTPases, which contain a CAAX box in their carboxyl terminus region, can undergo series of post-translational modifications that make them hydrophobic and facilitate their interaction with proteins, such as the Rho protein GDP dissociation inhibitor (Rho-GDI), or membranes [76,77]. These modifications include attachment of either farnesyl pyrophosphate (FPP; e.g., H-Ras) or geranylgeranyl pyrophosphate (GGPP; e.g., Rac1, Cdc42, and Rap1) to the cysteine residue of the CAAX motif by farnesylation or geranylgeranylation, respectively [77]. Farnesylation occurs at the CAAX motif when the sequence ends in any amino acid other than leucine and is catalyzed by farnesyl transferase (FTase) [78]. In contrast, geranylgeranylation occurs when the CAAX sequence ends in leucine and is catalyzed by geranylgeranyl transferase-I (GGTase-I) [79]. Various subunits of FTase and GGTase have been identified in islet $\beta$-cells [80]. The enzyme geranylgeranyl transferase-II (GGTase-II), also known as Rab geranylgeranyl transferase (Rab-GGTase) [81], has been identified in islet $\beta$-cells [82]. Rab-GGTase fails to recognize the CAAX box and requires an adaptor protein, the Rab escort protein (REP) [82], to exert its function. REP recruits newly synthesized Rab-GTPases and presents them to the Rab-GGTase [83]. Once a ternary complex is formed ( $\alpha$ and $\beta$ subunits of Rab-GGTase, REP, and the incoming 
Rab-GTPase), two geranylgeranyl groups are transferred onto the $C$ terminus of RabGTPase $[81,84]$, and REP-bound geranylgeranylated Rab is escorted to the respective target membrane (Figure 4).

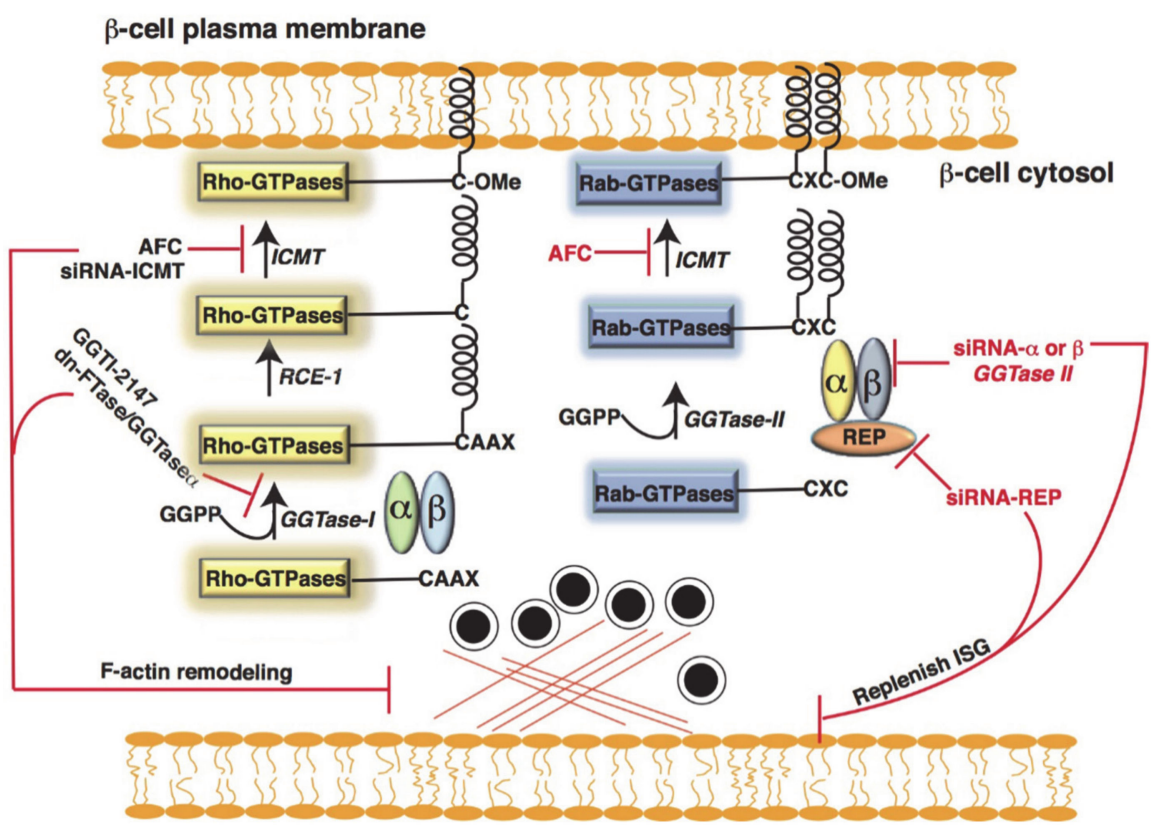

Figure 4. Post-translational modification of Rac1/Cdc42 and Rab-GTPases. The protein geranylgeranyl transferase-I (GGTase-I) transfers a geranylgeranyl group to proteins containing a C-terminal CAAX motif (where, C- cysteine, A- an aliphatic amino acid, and X- any amino acids). In contrast, Rab-GGTase does not recognize the CAAX motif, but requires an adaptor protein Rab escort protein (REP) to exert its function. REP recruits newly synthesized Rab-GTPases, and then presents them to the Rab-GGTase (GGTase-II). Once the geranylgeranyl group is inserted, as in the case of Rac1/Cdc42, the three terminal amino acids are removed by a Ras converting enzyme 1 (RCE-1). Furthermore, a methyl group is inserted onto the carboxylate anion of the prenylated cysteine via an ester linkage in the presence of S-adenosyl methionine by an enzyme protein-S-isoprenylcysteine O-methyltransferase (ICMT).

Extensive studies have been conducted in islet $\beta$-cells, wherein post-translational lipid modification (farnesylation and geranylgeranylation) was reduced using pharmacological agents such as lovastatin $[85,86]$ (a general inhibitor of the mevalonic acid biosynthesis pathway), structure-specific inhibitors, such as 3-allyl/vinyl-farnesols and 3-allyl/vinyl geranylgeraniols [87], and overexpression of dominant-negative FTase/GGTase-I, a common subunit of FTase or GGTase [63]. These studies demonstrated that inhibiting this lipid modification caused accumulation of the small GTPases in the soluble compartment rather than at the membrane, thereby reducing the interaction with effector proteins and attenuating GSIS.

Metabolic Dysfunction and Defective Post-Translational Modification of GTPase in Islet $\beta$-Cells

Increasing evidences demonstrate that the statin cholesterol-lowering drugs, which inhibit 3-hydroxy-3-methylglutaryl-CoA (HMG-CoA) reductase, reduce atherosclerotic cardiovascular burden [88], but are associated with increased incidence of new-onset T2D in a dose-dependent manner [89-92]. Several clinical studies demonstrated that statin therapy increased the incidence of diabetes, including Justification for the Use of Statins in Prevention: An Intervention Trial Evaluating Rosuvastatin (JUPITER) [93], in which a large, randomized, placebo-controlled, primary prevention trial demonstrated that rosuvastatin $(20 \mathrm{mg} /$ day $)$ decreased the incidence of adverse vascular events in the rosuvastatin group by $44 \%$, whereas saw an increase of $26 \%$ incidence of diabetes in the 
rosuvastatin group. Similarly, the prospective study of pravastatin in the elderly at risk found a $32 \%$ higher incidence of diabetes with pravastatin therapy [94]. A recent metaanalysis by Sattar et al. [90] included 13 randomized, placebo-controlled, and standard care controlled trials (including JUPITER and WOSCOP) with 91,140 participants. This metaanalysis revealed a $9 \%$ increase in the risk of diabetes incidence with little heterogeneity between trials, and the risk was more significant in elderly patients. In Diabetes Prevention Program Outcomes Study [95], the population at high risk for diabetes had significantly higher rates of diabetes with statin therapy. Taken together, statins may 'reveal' diabetes in individuals at high risk, depending on ethnicity, and results in a modest increase in diabetes risk.

Statins prevent de novo cholesterol biosynthesis and isoprenoid intermediates, such as farnesyl pyrophosphate (FPP) and geranylgeranyl pyrophosphate (GGPP) [96]. Several proteins, including Cdc42, Rac1, and Rho, undergo prenylation in islet $\beta$-cells by GGTase-I, whereas GGTase-II (also referred to as the Rab-GGTase) prenylates the Rab subfamily of proteins. Studies in $\beta$-cells have demonstrated that inhibition of GTPase prenylation causes defective GSIS due to defects in processes such as cytoskeletal remodeling, insulin secretory granule trafficking and fusion events $[82,96,97]$. For example, $\beta$-cell-specific deletion of geranylgeranyl pyrophosphate synthase (GGPPS), a protein prenylation enzyme, resulted in reduced GSIS coincident with fewer than normal insulin granules trafficking to the PM [98]. Furthermore, GGPP administration restored GSIS in GGPPS-null islets. In addition, GGPPS expression in $\mathrm{db} / \mathrm{db}$ mice is increased during the insulin compensatory period of T2D development, followed by a decrease during the $\beta$-cell dysfunction phase [98]. Thus, statins might affect $\beta$-cell function by disturbing protein prenylation.

\section{Rho-GTPases in Islet $\beta$-Cells}

\section{1. $C d c 42$}

Cdc42 plays an important proximal role in regulating islet $\beta$-cell function $[47-49,65,99]$. Studies using GTP $\gamma$ S, a non-hydrolyzable G-protein-activating analog of GTP, demonstrated that the formation of Cdc42-GTP (active conformation) is required for Cdc42 to translocate to the PM [66]. Post-translational prenylation is key for the association of Cdc42 with the inhibitory protein Rho-GDI in $\beta$-cells; exposure to a prenylation inhibitor prevents the association of Cdc42 with Rho-GDI [50]. Second-phase insulin release requires mobilization of insulin granules located deep inside the intracellular storage pools toward the PM and involves glucose-induced remodeling of the actin cytoskeleton [100-102], a process involving the localized and transient conversion of filamentous actin to globular actin (F-actin to G-actin) to permit granule movement through the network.

Cdc42 activation in response to glucose stimulation was found to occur early during the first-phase of GSIS ( 2-3 min) [65]. The activated form (Cdc42-GTP) localizes to the PM [48], after which it cycles back to Cdc42-GDP due to the glucosylation of Cdc42 [47]. The timing of Cdc42 activation/deactivation correlated with the visualization of F-actin depolymerization and repolymerization, consistent with the hypothesis that GSIS is regulated by Cdc42 cycling. Furthermore, expression of the Q61L constitutively-active mutant of Cdc42 yielded blunted cortical actin depolymerization that correspondingly inhibited GSIS [47]. Cdc42 was found to co-localize with VAMP2-containing insulin secretory granules in pancreatic $\beta$-cells and to translocate to the PM when stimulated with glucose. Cdc42-VAMP2 complexes in the PM were also found to associate with syntaxin 1A, further promoting insulin granule fusion and release [48].

Surprisingly, the caveolar protein Caveolin1 (Cav-1) was also identified as GDI for Cdc42, specifically for the pool of Cdc42 which localizes to the insulin granules-in this location, Cav-1 forms a heterotrimeric complex with Cdc42 and VAMP2 [49]. Cav-1 contains a Ras binding domain, which mediates a direct interaction with Cdc42 [49]. Cav-1 dissociates from the Cdc42-VAMP2 complex upon glucose stimulation at the same time that Cdc42 associates with $\beta$-Pix [103], a $\beta$-cell GEF for Cdc42. Depletion of Cav- 1 from isolated islets and clonal MIN6 $\beta$-cells was shown to elevate basal insulin release and attenuate 
GSIS, simulating the $\beta$-cell dysfunction associated with T2D [49]. Consistent with the role of Cav-1 as a GDI for Cdc42, with Cdc42 activation in the $\beta$-cell being upstream of ERK1/2, Cav-1 deficient $\beta$-cells showed increased activities of ERK1/2; this triggered events related to proliferation, such as downregulated cell cycle inhibitors (e.g., FOXO1 and GSK3 $\beta$ ) and upregulated expression of Cyclin D2 and Cyclin D3 [104,105]. Intriguingly, whole body Cav-1 knockout mice fed a high fat diet showed less $\beta$-cell apoptosis than control mice [106], whereas Cav-1 overexpression in MIN6 $\beta$-cells exacerbated the palmitate-induced increase in $\beta$-cell apoptosis [104]. These findings add to the growing body of knowledge suggesting that $\beta$-cells toggle between function (GSIS) and proliferative states.

In further support of a key role for Cdc42 in the $\beta$-cell in regard to whole body glucose homeostasis, mice lacking the Cdc42 gene in pancreatic $\beta$-cells (Rip-CDC42cKO) were shown to display glucose intolerance and decreased GSIS, without alterations to islet morphology [107]. Furthermore, Rip-CDC42cKO mice showed reduced signaling via the ERK1/2-NeuroD1 pathway and attenuated insulin expression. Together, these data supported the earlier in vitro findings demonstrating $\mathrm{Cdc} 42$ to be an essential modulator of GSIS in pancreatic $\beta$-cells [107]. An additional study has demonstrated that miR-29a targets the Cdc42 mRNA 3'-UTR and negatively regulates Cdc42 and the downstream molecule $\beta$-catenin, inhibiting proliferation and insulin secretion in the clonal MIN6 $\beta$-cell line [108]. Furthermore, human islet perifusion assays further demonstrated that overexpression of miR-29 inhibited GSIS [109]. Beta cell-specific transgenic miR-29a/b/c overexpressing mice have an increased susceptibility for high-fat diet-induced glucose intolerance compared to control mice [109]. Future studies using an inducible $\beta$-cell specific miR-29a overexpressing mouse model will be important to assess this potential linkage of miR-29a and Cdc42 in the context of biphasic GSIS and $\beta$-cell viability.

Defects in lipid homeostasis are closely associated with insulin secretion defects, a key feature of T2D. In a recent study, depletion of ABCA12, a lipid transporter protein in mouse $\beta$-cells, resulted in impaired GSIS, islet inflammation, and $\beta$-cell death [110]. In particular, the impaired GSIS was linked to defects in the biogenesis and fusion of insulin secretory granules that were associated with dysregulated Cdc42-induced actin cytoskeletal remodeling [110]. Taken together, impairments in small GTPases within islet $\beta$-cells clearly contribute toward the etiology of T2D [97,98,110,111].

\section{2. $R a c 1$}

In $\beta$-cells, Cdc42 activation and cycling leads to the activation of Rac1, and knockdown of Cdc42 reduces the activation of Rac1 [65]. The importance of Rac1 activation and cycling in islet $\beta$-cells was first demonstrated using Clostridium difficile toxins $\mathrm{A}$ and $\mathrm{B}$, which irreversibly monoglucosylate and inactivate Rac1 [53]. Using an inactive mutant of Rac1 (N17Rac1), Li et al. [54] demonstrated that activation of Rac1 (Rac1-GTP) is required for its translocation to the inner leaflet of the PM, and this translocation occurs immediately before the disappearance of F-actin structures, wherein this F-actin depolymerization is known to underlie insulin granule mobilization to the cell surface to support the second phase of GSIS.

These observations were later corroborated using $\beta$-cell-specific Rac1 knockout mice [112]. The $\beta \mathrm{Rac}^{-/-}$mice were developed by crossing Rac1 $1^{\text {flox } / \text { flox }}$ mice, which harbor a modified endogenous Rac1 gene in which exon1 is flanked by loxP sites, with those that express the Cre recombinase gene under the control of the rat insulin-2 gene. $\beta \mathrm{Rac}^{-/-}$mice developed glucose intolerance and hypoinsulinemia, despite normal islet density and $\beta$-cell mass [112]. While a line of $\beta$-cell-specific N17Rac1 (RIP-RacN17) mice has also been generated and phenotyped, neither glucose tolerance nor insulinemia levels have been evaluated [113]. To determine whether Rac1 activation is required in $\beta$-cells in vivo, it will be interesting to compare the phenotypes of mice with N17Rac1 versus WT Rac1 expressed in the context of the $\beta$-cell-specific Rac1 KO background.

Additional evidence supporting the importance of Rac1 activation in the $\beta$-cell comes from pharmacologic studies using NSC23766 and Ehop-016 [64,114]. NSC23766, a chemical 
compound that inhibits Rac1-GEF interaction [115] and prevents glucose-induced Rac1 activation, inhibits Rac1 trafficking to the cell surface, correlating with the loss of GSIS, in INS-1 832/13 cells and rat islets [64]. $\beta$-cell-specific knockdown of the Rac1-GEF Tlymphoma and invasive metastatic protein (Tiam1) produces a similar phenotype [64]. In addition to Tiam1, Vav2 has been identified as a GEF in the regulation of Rac1-mediated GSIS and actin remodeling; this was confirmed using a small molecule inhibitor of the Vav2-Rac1 interaction: Ehop-016 [114]. Vav2-GEF activity can be regulated by tyrosine phosphorylation [116,117]. Several Src family tyrosine kinases, such as Lck, Fyn [118,119], and Syks (Syk and Zap70) [119,120], as well as receptor tyrosine kinases [121-123], have been implicated as mediators of Vav2 tyrosine phosphorylation. Recently, the tyrosine kinase Yes (a Src family kinase) has been reported to regulate Cdc42 activation in a glucosedependent manner in pancreatic $\beta$-cells [124]. It remains untested whether Cdc42 and Rac1 are both activated by Yes kinase; such a hypothesis is intriguing, although it is important to note that activation of Cdc42 and Rac1 occur as temporally distinct events in $\beta$-cells $[47,48,65]$.

\subsection{Rho-GDI}

Cdc42 and Rac1 share an inhibitory GDI regulator, Rho-GDI, which sequesters RhoGTPases to prevent dissociation of GDP and prevent translocation to the membrane for GEF interaction and activation. Overexpression of the WT Rho-GDI significantly attenuated glucose-induced, but not $\mathrm{KCl}$ - or Mastoparan (peptide toxin from wasp venom and global activator of GTPases)-induced, insulin secretion. Conversely, siRNA-mediated knockdown of endogenous Rho-GDI increased GSIS [125,126]. Together, these studies suggested an inhibitory role for Rho-GDI in GSIS.

Dissociation of Rho-GTPases from Rho-GDI is a vital step in the activation of GTPases. Studies in $\beta$-cells have demonstrated a temporal and spatial difference between Cdc42 and Rac1 interactions with Rho-GDI [65,125]. Co-immunoprecipitation studies have revealed that Rho-GDI-Cdc42 complexes in $\beta$-cells dissociate within 3 min after stimulation with glucose, correlating with the timing of Rho-GDI tyrosine (Tyr-156) phosphorylation [65]. Glucose-induced disruption of Rho-GDI-Rac1 complexes occurred around $15 \mathrm{~min}$, an event coupled with Rac1 activation [125]. Interactions between Rho-GTPases and RhoGDIs can be regulated by post-translational phosphorylation, sumoylation, acetylation, and oxidation. Phosphorylation of Rho-GDIs decreases their affinity for Rho-GTPases, thereby promoting the release of Rho-GTPases and their subsequent activation by RhoGEFs $[127,128]$. For example, phosphorylation of Rho-GDI1 by protein kinases, such as Src, PKC $\alpha$, p21 activated kinase 1 (PAK1), and FER, facilitate the release of specific Rho-GTPases and their subsequent spatiotemporal activation [129-133]. Rho-GDI-Rac1 dissociation was blocked by the Rho-GDI mutations Y156F and S101A/S174A, which block phosphorylation, suggesting a spatiotemporal regulation of Rho-GDI-Rac1/Cdc42 disruption and Cdc42/Rac1 activation in $\beta$-cells [65,125]. Src phosphorylates Rho-GDI1 at Tyr156 to promote translocation of Rho-GDI to the PM and local activation of RhoA, Rac1, and Cdc42 [129]. Yes kinase is implicated in phosphorylation of Cav- 1 in $\beta$-cells, wherein Cav-1 acts as a GDI for Cdc42 in the insulin secretory granules [124]. It will be important to clarify if Yes kinase also disrupts the Cdc42-Rho-GDI complex in $\beta$-cells. Rho-GDI1 phosphorylation at Ser101 and Ser174 by PAK1 promotes dissociation and activation of Rac1, but not RhoA [132].

PAK1 activation by Rac1 and Cdc42 regulates insulin release; therefore, there may exist positive feedback between PAK1 activation and Rho-GDI phosphorylation for Rac1 signaling. However, phosphorylation of Rho-GDIs does not always induce the disruption of the GTPase-GDI complex. Cyclic AMP-dependent protein kinase A (PKA) phosphorylates Rho-GDI1 at Ser174 and RhoA at Ser188, which increases the affinity of Rho-GDI1 to RhoA, thereby inhibiting RhoA signaling $[134,135]$. Protein phosphatase 1B dephosphorylates Rho-GDI1 to decrease Rho-GDI1 interaction with 14-3-3ı and activate Rho-GTPases [136]. 
Therefore, reversible phosphorylation of Rho-GDIs by a kinase/phosphatase could be a critical mechanism for precisely regulating the spatiotemporal activation of Rho-GTPases [137].

In addition, lipid kinases such Phospholipase D (PLD) or Phosphatidylinositol-4phosphate 5-kinase (PIP5K) are targets of Rho-GTPases [138], as phospholipids (phosphatidylinositol 4,5-bisphosphate (PIP2), phosphatidic acid (PA)) may also act as Rac/Cdc42Rho-GDI complex disruption agents [139-141] (Figure 5). The presence of acidic phospholipids such as PIP2 and PA can promote the release of Rho-GTPases from Rho-GDIs [142,143]. Phospholipids mediate a partial opening of the complex that exposes the GTPases to GEFs [144]. A possible mechanism could involve competition of the active lipids for Rho binding sites on the GDI protein. Analysis of the primary structure of human Rho-GDI reveals a single hydrophobic region (amino acids 50-80) and this region can interact with the hydrophobic isoprenyl group at the $C$ terminus of Rho-GTPases, consistent with the known requirement of this modification for the binding of Rho family proteins to Rho-GDI [139].

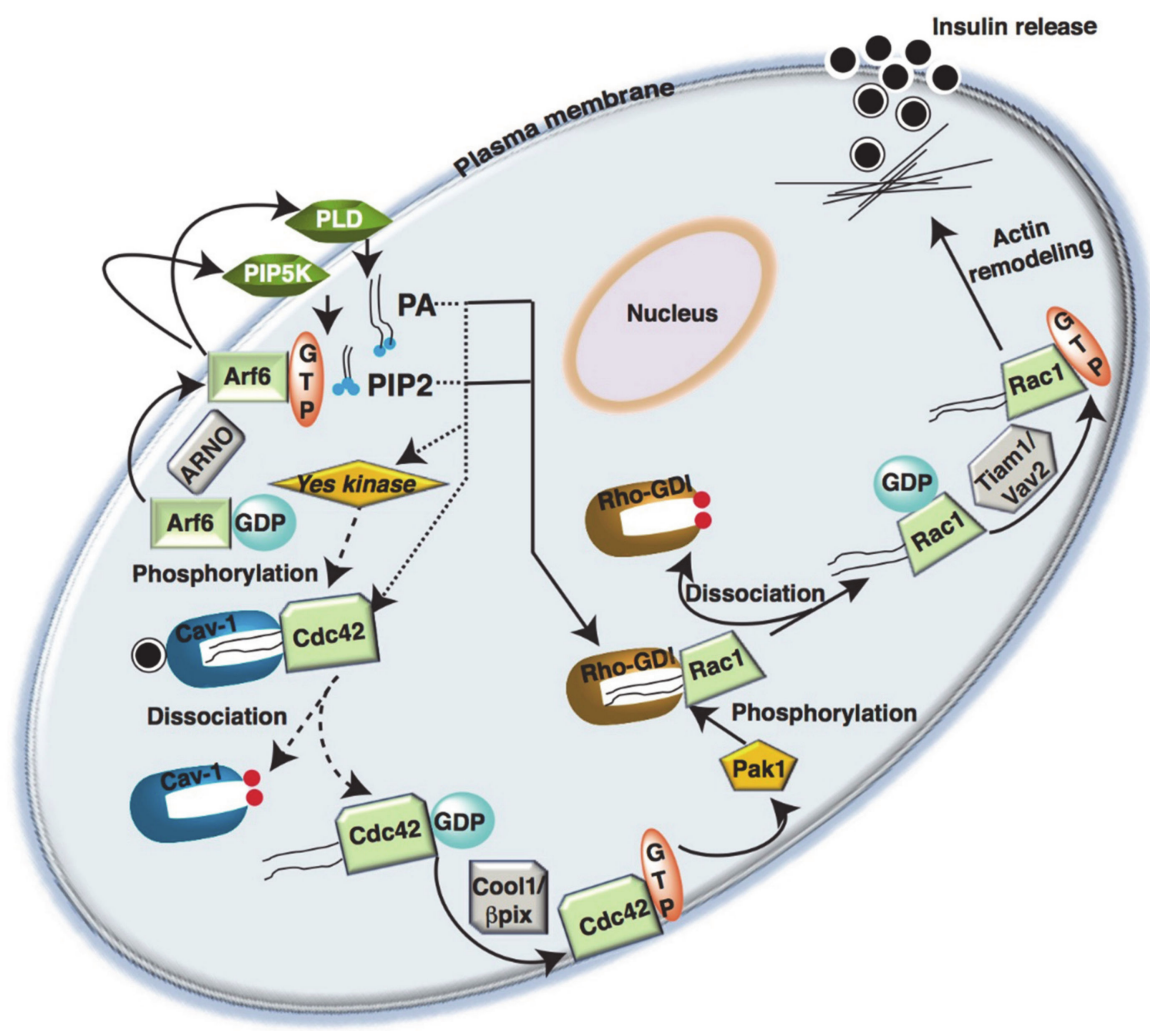

Figure 5. Cross-talk between Arf6 and Rho-GTPases in islet $\beta$-cell insulin secretion. Glucose metabolism leads to activation of Arf6, which initiates the activation of membrane associated phospholipase D (PLD) and phosphatidylinositol-4-phosphate 5-kinase (PIP5K) to generate fusogenic lipids such as phosphatidylinositol 4,5-bisphosphate (PIP2) and phosphatidic acids (PA). The lipids generated facilitate the dissociation of Cdc42 from Cdc42/Caveolin-1 complex present in the insulin containing vesicle, when the caveolin- 1 is phosphorylated by a Yes kinase, and subsequent activation by Cool/ $\beta$-pix (GEF). The activated Cdc42 activates Pak1, which phosphorylates and activates Rac1/GDI. This leads to exchange of GDP/GTP to initiate cytoskeletal rearrangement for insulin granule mobilization and release.

\section{Rac1 and Oxidative Stress in T2D Islet $\beta$-Cells}

$\beta$-cells are highly susceptible to oxidative stress due to their relatively low levels of antioxidant enzymes, such as catalase and glutathione peroxidase [145]. There are several sources of reactive oxygen species (ROS) production in $\beta$-cells: nonenzymatic glycosylation [146], the electron transport chain in mitochondria [147], and the hexosamine pathway [148]. Recently, $\beta$-cells have been shown to express NADPH oxidase (NOX2) [149], which is predominantly localized at the PM. Glucose, palmitate, and pro-inflammatory 
cytokines modulate expression via post-translational modification of the p47 ${ }^{\text {phox }}$ NOX2 subunit; these cytokines also modulate NOX2 activity in rat pancreatic islets and clonal $\beta$-cells [150]. The NOX macromolecular complex consists of several subunits, including two membrane subunits (gp91 ${ }^{\text {hhox }}$ and $\mathrm{p} 22^{\text {phox }}$ ), three cytosolic subunits (p47 ${ }^{\text {phox }}, \mathrm{p} 67^{\text {phox }}$, and $\mathrm{p} 40^{\text {phox }}$ ), and the small GTPase Rac1 [151]. It has also been shown that activation of Rac1 is vital for the holoenzyme assembly and activation of NOX [152]. Indeed, protein levels of active Rac1, NOX activity, ROS generation, Jun NH2-terminal kinase (JNK) 1/2 phosphorylation, and caspase-3 activity were significantly higher in Zucker diabetic fatty rat (ZDF) islets and T2D human islets [153,154]. Inhibition of Rac1 activation significantly attenuates NOX2-driven p38MAPK phosphorylation, implicating a regulatory role for Rac1 in promoting NOX2-p38MAPK signaling in $\beta$-cell [155]. In T1D, Rac1, a part of NOX2, is involved in the generation of ROS under the duress of cytokine stress. Furthermore, NSC23766, a small inhibitor of Rac1-Tiam1 signaling module prevented the spontaneous on set of diabetic phenotype in NOD mice. The prevention of diabetes is due to significant inhibition of Rac1 expression and activity, which is otherwise significantly elevated in NOD mice without NSC23766 treatment [156]. The mechanism by which Rac1 regulates two seemingly opposing phenomena in the $\beta$-cell, i.e., promoting GSIS and NOX2 activation, is still under scrutiny. A plausible explanation could be that inhibition of geranylgeranylation constitutively activates Rac1 $[97,98,157]$.

\subsection{Arf}

Arf belongs to the Ras superfamily [44]. Similar to Cdc42 and Rac1, Arf6 associates with the inner leaflet of the PM in a GTP-dependent manner, and removal of GTP is needed to dissociate Arf6 from the PM [158]. At the PM, Arf6 directly activates membrane lipidmodifying enzymes, such as PIPK5 [159] and PLD [160], which leads to the production of PIP2 and PA, respectively [161]. The generation of PIP2 at the PM is critical for Arf6 mediated endocytosis, endosomal recycling, PM remodeling, and actin polymerization [161]. In $\beta$-cells, expression of a dominant-inhibitory Arf6 mutant, Arf6(T27N), impaired GSIS in the pancreatic MIN6 $\beta$-cell line [162]. In response to membrane depolarization, MIN6 cells expressing Arf6(T27N) showed loss of second-phase insulin secretion, with normal first phase secretion, consistent with the roles for small GTPase cycling in the actin remodelingbased second phase of GSIS. One caveat in this study is that the authors derived their conclusions from MIN6 clonal $\beta$-cells, and did not confirm the findings in primary islet $\beta$-cells. Although the basal levels of PIP2, derived from PIPK5, are sufficient to keep a pool of insulin secretory granules primed and ready for release during the first phase of secretion [162], Arf6 plays a crucial role in the priming of insulin secretory granules to support second-phase insulin secretion.

Furthermore, the Arf nucleotide binding site opener (ARNO) was identified as a GEF for Arf6 in $\beta$-cells [163] and overexpression of ARNO inactive mutants and secinH3, a selective pharmacological inhibitor of ARNO/Arf6, inhibited Arf6, Cdc42, and Rac1 activation and GSIS in INS-1 832/13 cells and rodent islets [163], suggesting that ARNO/Arf6 might be upstream of Cdc42 and Rac1 activation. These studies could also be recapitulated using RNA interference (RNAi) experiments, where the authors demonstrated that reducing ARNO expression completely suppressed glucose-induced activation of Rac1. Multiple signaling pathways are postulated to emanate from Arf6 activation in $\beta$-cells, including the regulation of mTOR and p70S6K, based upon studies performed in MIN6N8 cell line $[164,165]$. High glucose induced the binding of Arf6 to PLD1, a protein that catalyzes the hydrolysis of phosphatidylcholine to generate PA and choline [166]. PLD1 has been implicated in glucose-induced mTOR and p70S6K signaling in the $\beta$-cell, tentatively placing it downstream of Arf6, although this mechanistic placement awaits further experimental evidence using specific Arf6 and PLD1 genetic and pharmacologic tools. 


\subsection{Rab-GTPases}

Rab-GTPases, the largest family of small GTPases, regulate intracellular membrane traffic $[167,168]$. Different Rab-GTPases localize to separate membrane compartments, thereby controlling the specificity and directionality of membrane trafficking, serving as membrane identity markers [169-171]. Rab3A was the first Rab-GTPase identified on insulin-containing secretory granules. Using mouse Rab3a knockout [70,172], and overexpression models [173-176], researchers demonstrated that Rab3a is required for normal insulin secretion and the control of plasma glucose levels. Rab27A, a close evolutionary relative of Rab3, is also associated with insulin secretory granules [70,177,178]. In studies using Rab27a-deficient mice $[70,170,171]$ or Rab27a overexpressing mice $[67,179]$, it is clear that Rab27a regulates insulin release. Ashen mice carry a point mutation resulting in excision of Rab27a, and Ashen $\beta$-cells show disrupted refilling of the readily releasable pool of insulin secretory granules in response to stimulatory glucose, potentially placing Rab27a as a regulator of second phase GSIS. In contrast, Rab3a ${ }^{-1-}$ mice exhibited normal refilling of the readily releasable pool, distinguishing the role of Rab3a from that of Rab27a $[175,176,180]$.

The Rab27a effector, granuphilin, localizes to insulin granules [181] at the PM. Granuphilin associates with the t-SNARE protein syntaxin $1 \mathrm{~A}$, as demonstrated by co-immunoprecipitation and in vitro binding assays [67]. Overexpression of a granuphilin mutant that impairs granuphilin binding to Rab27a or syntaxin 1A causes dysfunctional GSIS [67,180,181], supporting the concept that granuphilin plays a role in connecting specific pools of insulin secretory granules to specific SNARE proteins at the PM.

Two other types of Rab27a effectors, Synaptotagmin-like proteins (Slps) and the related Slac2 proteins, which are Slps lacking C2 domains; each harbor a unique amino-terminal domain that confers binding to Rab27 [182,183]. One in particular, Slac2c/MyRIP (Myosin VIIA and Rab Interacting Protein), is also associated with the secretory granules of $\beta$ cells [179]. Slac2c/MyRIP knockdown impairs GSIS. $\beta$-cells express Myosin-Va, a potential binding partner of Slac2c/MyRIP [179]. Indeed, overexpression of just the actin-binding domain of Slac2c/MyRIP suppressed insulin granule exocytosis, suggesting Rab27a and Slac2c/MyRIP co-regulate the interaction of secretory granules with the cortical actin cytoskeleton and participate in insulin exocytosis.

Beyond Rab27a and Rab3, two other Rab-GTPases are implicated in $\beta$-cells: Rab2a and Rab37. While Rab27a regulates the late stage of the secretory process by facilitating granule recruitment to the fusion site, Rab2a functions in the early stage of insulin granule biogenesis; however, both bind to the same Rab effector protein, Noc2 (Nucleolar complex protein 2 also known as RPH3AL). The GTP-dependent ternary Rab2a-Noc2-Rab27a complex specifically localizes on perinuclear immature granules, whereas the binary Noc2-Rab27a complex localizes on mature granules at the PM. Noc2 mutants defective in binding to Rab2a or Rab27a were found to inhibit GSIS, while knockdown of Rab2a or Noc2 impairs the maturation of insulin secretory granules [69]. Rab37 is essential for GSIS, regulating the number of granules in close proximity to the PM. Interestingly, Rab37 does not bind to any of the effectors of Rab3a or Rab27a, suggesting the effectors linking Rab37-GTP and GSIS remain to be found [68]. Nevertheless, the Rab-GAP TBC1D1 has been implicated as a required Rab cycling protein given that TBC1D1-knockout $\beta$-cells harbor increases in insulin granule density and number of docked granules, supporting the observed elevated first- and second-phase insulin release [184].

\section{Arf6 and Rab27a Couple Exocytosis and Endocytosis}

Exocytosis-endocytosis coupling in the pancreatic $\beta$-cell was first demonstrated by Orci et al. [185]; this coupling is essential to maintain PM homeostasis, as the extra portion of the lipid membrane added during the exocytosis of insulin granules is cleaved to maintain the original structure of the PM and cellular circumference/size [186]. GSIS is coupled to the budding/endocytosis of PM material [185]. Conventional endocytosis, as reported in other cell types [187-189], involves recruitment of clathrin, which, along 
with a host of adaptor proteins, initiates an inward curvature of the PM. Then, dynamin GTPase facilitates the constriction and excision of the endocytotic vesicle from the PM [189]. In pancreatic $\beta$-cells, glucose also promotes phosphatidylinositol $(3,4,5)$-trisphosphate (PIP3) generation through phosphoinositide 3-kinase (PI3K), and further recruits ARNO and EPI64 (Rab27a-GAP) to the inner leaflet of the PM, where ARNO promotes clathrin assembly via Arf6 and synchronizes early endocytosis [190,191]. On the other hand, Rab27a facilitates exocytosis $[179,192,193]$ (see Section 5.4). Thus, these results indicate that the glucose-induced activation of PI3K plays a pivotal role in exocytosis-endocytosis coupling, and that ARNO and EPI64 regulate endocytosis at distinct stages [179,190-193].

\subsection{Rap-GTPases}

Rap1 GTPase and its GEF, Epac2, are the major forms of their respective families in islet $\beta$-cells [194-196]. Rap1 activity is maintained by the PKA-mediated phosphorylation of Rap1-GAP, thus disallowing Rap-GAP to hydrolyze GTP from Rap1 [197,198]. A PKAindependent pathway involves the Rap1-GEF, Epac2. [199]. In mouse islets, a PKA inhibitor (H89) and Epac2 antisense oligonucleotide (ASOs) each partially inhibited glucagon-like peptide-1 (GLP-1)-induced potentiation of GSIS, while the combined treatment had an additive effect [200]. Rap1 is also known to enhance islet cell proliferation exclusively via mammalian target of rapamycin complex 1 [201].

Rap1 signaling through Epac2 facilitates the insulin release enhancing effects of GLP-1. GLP-1 binds to its cognate GLP-1 receptor (GLP1R), a G-protein coupled receptor found largely on the surface of pancreatic $\beta$-cells (as well as $\alpha$ - and $\delta$-cells) [202,203], which increases the intracellular cAMP levels by activating transmembrane associated adenylate cyclases (TMACs) [204] and potentiating insulin secretion. Indeed, GLP1R agonists, such as GLP-1, are used clinically to increase insulin release from residual endogenous $\beta$-cells of the T2D islet [205-207]. Most recently, an Epac2 activator was shown to activate Cdc42 [111], which is potentially another instance where small GTPase regulatory proteins are used by multiple GTPases in the $\beta$-cell. Further studies are required to delineate the multiple effects of Epac2 in $\beta$-cells. Nevertheless, current data suggest that most GLP1R signaling is mediated by PKA, Epac2-Rap1, and Cdc42 in $\beta$-cells. Additionally, activation of Rap1 binds to and activates phospholipase C- $\varepsilon$. PLC- $\varepsilon$ initiates the generation of diacylglycerol (DAG) and inositol trisphosphate (IP3). DAG and $\mathrm{Ca}^{2+}$ activate protein kinase C (PKC), and $\mathrm{PKC}$ phosphorylates secretory granule-associated proteins, thereby increasing insulin granule exocytosis [208,209].

\section{Identification of GTPase Regulating Proteins as T2D Candidate Genes}

T2D genome-wide association analysis meta-analysis revealed two IQ-motif-containing GAPs (IQGAP1 and IQGAP2), involved in cellular signaling, cytoskeletal organization, and GSIS [210] in the top $95^{\text {th }}$ percentile for association with T2D; providing evidence for IQGAP2 contribution to insulin resistance [211]. Recently, a GEF for Rac1, P-Rex1, which is activated by PIP3 via PI3K, has been shown to play a critical role in GSIS in insulin-secreting INS-1 832/13 cells [212]. Single nucleotide polymorphism analysis of the $3^{\prime}$ perigenic region of P-Rex1 was found to be associated with an increased risk of obesity and T2D development. In humans, the P-Rex1 locus is near a region on chromosome 20 which is associated with T2D (20q12-13.1) [213]. TBC1D4, a Rab-GAP, was recently identified in GWAS as a T2D-associated SNP in Greenlandic individuals, and is known to cause insulin resistance in skeletal muscle [214]. TBC1D4 has been identified in human and mouse pancreatic $\beta$-cells, and TBC1D4 mRNA expression was found to be downregulated in pancreatic islets from individuals with T2D [215]. Furthermore, TBC1D4 knockdown decreased GSIS from a MIN6 $\beta$-cell line [215] and human EndoC- $\beta$ H1 cells [216]. The human Rho-GEF11 (ARHGEF11) R1467H variant in a German Caucasian cohort was linked to impaired glucose tolerance and increased susceptible to T2D, implicating a GTPase regulatory protein and T2D risk [217]. As such, $\beta$-cell defects in insulin secretion could be caused by dysregulated GTPase regulatory proteins. 


\section{Conclusions}

In this review, we summarize the evidence for the role of different small GTPases in the islet insulin secretory process, including actin cytoskeletal rearrangement, vesicle trafficking, and vesicle fusion. We also review how these GTPases are regulated and the associated regulatory factors that play a vital role in $\beta$-cell function. Furthermore, we describe how the functional impairment of GTPases can lead to $\beta$-cell dysfunction and how GTPase signaling can revive otherwise dysfunctional $\beta$-cells. However, this research area is in its infancy, and further mechanistic in vivo studies are required, which will lead to future discoveries.

\section{Future Directions}

More research is needed to understand how GTPase cycling coordinates to facilitate second-phase insulin secretion, a process that requires actin cytoskeleton dynamic changes with signaling cues to fill the insulin secretory granule pools. It will also be important to determine the spatiotemporal regulation of Rho-GDI in sequestering active GTPases in their inactive forms and to understand how several GEFs coordinate the activities of the GTPases Rac1 and Cdc42.

Similarly, cross-talk between several Rab and Ras family GTPases in granule docking and priming, and their roles in biphasic insulin secretion, remain unresolved. New methodologies are required to study the spatiotemporal regulation of GTPases in response to the dynamic changes in the intracellular locations of Rho-GEF, Rho-GAP, and Rho-GDI. Optogenetics allows researchers to reversibly trigger signaling with spatial and temporal control in the sub-second range when combined with genetically encoded biosensors and real-time nuclear magnetic resonance (RT-NMR) experiments allow the collection of spectra for kinetic analyses of exchange or hydrolysis of GTPases. Such assays will provide new evidence to unveil the role of GTPases in control of $\beta$-cell insulin granule mobilization, tethering, docking, priming, and fusion in real time.

Author Contributions: Conceptualization, R.V. and D.C.T.; writing-original draft preparation, R.V. and D.C.T.; and writing-review and editing, R.V. and D.C.T. Both authors contributed substantially to the work. All authors have read and agreed to the published version of the manuscript.

Funding: This study was supported by grants from the National Institutes of Health (DK067912 and DK112917 to D.C.T., and DK102233 to D.C.T. and R.V.), the Juvenile Diabetes Research Foundation (17-2013-454 to D.C.T.), and the Wanek Project to Cure Type 1 Diabetes at the City of Hope to D.C.T.

Institutional Review Board Statement: Not applicable.

Informed Consent Statement: Not applicable.

Data Availability Statement: Not applicable.

Acknowledgments: We acknowledge the contributions and support of our former and current laboratory associates and collaborators, especially Anjan Kowluru to the area of islet biology reviewed in this article. We apologize to those whose important work was not cited due to space limitations. Nancy Linford, provided editing assistance.

Conflicts of Interest: The authors declare no conflict of interest.

\section{References}

1. Cerasi, E. Mechanisms of glucose stimulated insulin secretion in health and in diabetes: Some re-evaluations and proposals. Diabetologia 1975, 11, 1-13. [CrossRef] [PubMed]

2. Cerasi, E. Potentiation of insulin release by glucose in man. II. Role of the insulin response, and enhancement of stimuli other than glucose. Acta Endocrinol. 1975, 79, 502-510. [CrossRef]

3. Chadt, A.; Al-Hasani, H. Glucose transporters in adipose tissue, liver, and skeletal muscle in metabolic health and disease. Pflug. Arch. Eur. J. Physiol. 2020, 472, 1273-1298. [CrossRef]

4. Berger, C.; Zdzieblo, D. Glucose transporters in pancreatic islets. Pflug. Arch. Eur. J. Physiol. 2020, 472, 1249-1272. [CrossRef] [PubMed] 
5. Ashcroft, F.M.; Proks, P.; Smith, P.A.; Ammala, C.; Bokvist, K.; Rorsman, P. Stimulus-secretion coupling in pancreatic beta cells. J. Cell. Biochem. 1994, 55, 54-65. [CrossRef]

6. Doliba, N.M.; Qin, W.; Najafi, H.; Liu, C.; Buettger, C.W.; Sotiris, J.; Collins, H.W.; Li, C.; Stanley, C.A.; Wilson, D.F.; et al. Glucokinase activation repairs defective bioenergetics of islets of Langerhans isolated from type 2 diabetics. Am. J. Physiol. Endocrinol. Metab. 2012, 302, E87-E102. [CrossRef]

7. Gembal, M.; Detimary, P.; Gilon, P.; Gao, Z.Y.; Henquin, J.C. Mechanisms by which glucose can control insulin release independently from its action on adenosine triphosphate-sensitive K+ channels in mouse B cells. J. Clin. Investig. 1993, 91, 871-880. [CrossRef]

8. Matschinsky, F.M. Banting Lecture 1995. A lesson in metabolic regulation inspired by the glucokinase glucose sensor paradigm. Diabetes 1996, 45, 223-241. [CrossRef]

9. Prentki, M.; Corkey, B.E.; Madiraju, S.R.M. Lipid-associated metabolic signalling networks in pancreatic beta cell function. Diabetologia 2020, 63, 10-20. [CrossRef]

10. Rorsman, P.; Braun, M. Regulation of insulin secretion in human pancreatic islets. Annu. Rev. Physiol. 2013, 75, 155-179. [CrossRef]

11. Seino, S.; Shibasaki, T.; Minami, K. Dynamics of insulin secretion and the clinical implications for obesity and diabetes. J. Clin. Investig. 2011, 121, 2118-2125. [CrossRef]

12. Henquin, J.C.; Dufrane, D.; Gmyr, V.; Kerr-Conte, J.; Nenquin, M. Pharmacological approach to understanding the control of insulin secretion in human islets. Diabetes Obes. Metab. 2017, 19, 1061-1070. [CrossRef]

13. Henquin, J.C.; Nenquin, M.; Stiernet, P.; Ahren, B. In vivo and in vitro glucose-induced biphasic insulin secretion in the mouse: Pattern and role of cytoplasmic Ca2+ and amplification signals in beta-cells. Diabetes 2006, 55, 441-451. [CrossRef]

14. Omar-Hmeadi, M.; Idevall-Hagren, O. Insulin granule biogenesis and exocytosis. Cell. Mol. Life Sci. CMLS 2021, 78, 1957-1970. [CrossRef]

15. Arous, C.; Halban, P.A. The skeleton in the closet: Actin cytoskeletal remodeling in beta-cell function. Am. J. Physiol. Endocrinol. Metab. 2015, 309, E611-E620. [CrossRef]

16. Sekine, N.; Cirulli, V.; Regazzi, R.; Brown, L.J.; Gine, E.; Tamarit-Rodriguez, J.; Girotti, M.; Marie, S.; MacDonald, M.J.; Wollheim, C.B.; et al. Low lactate dehydrogenase and high mitochondrial glycerol phosphate dehydrogenase in pancreatic beta-cells. Potential role in nutrient sensing. J. Biol. Chem. 1994, 269, 4895-4902. [CrossRef]

17. McCommis, K.S.; Hodges, W.T.; Bricker, D.K.; Wisidagama, D.R.; Compan, V.; Remedi, M.S.; Thummel, C.S.; Finck, B.N. An ancestral role for the mitochondrial pyruvate carrier in glucose-stimulated insulin secretion. Mol. Metab. 2016, 5, 602-614. [CrossRef]

18. Meredith, M.; Rabaglia, M.; Metz, S. Cytosolic biosynthesis of GTP and ATP in normal rat pancreatic islets. Biochim. Biophys. Acta 1995, 1266, 16-22. [CrossRef]

19. Meredith, M.; Rabaglia, M.E.; Metz, S.A. Evidence of a role for GTP in the potentiation of $\mathrm{Ca}(2+)$-induced insulin secretion by glucose in intact rat islets. J. Clin. Investig. 1995, 96, 811-821. [CrossRef]

20. Metz, S.A.; Meredith, M.; Rabaglia, M.E.; Kowluru, A. Small elevations of glucose concentration redirect and amplify the synthesis of guanosine 5'-triphosphate in rat islets. J. Clin. Investig. 1993, 92, 872-882. [CrossRef]

21. Stark, R.; Pasquel, F.; Turcu, A.; Pongratz, R.L.; Roden, M.; Cline, G.W.; Shulman, G.I.; Kibbey, R.G. Phosphoenolpyruvate cycling via mitochondrial phosphoenolpyruvate carboxykinase links anaplerosis and mitochondrial GTP with insulin secretion. J. Biol. Chem. 2009, 284, 26578-26590. [CrossRef]

22. Kibbey, R.G.; Pongratz, R.L.; Romanelli, A.J.; Wollheim, C.B.; Cline, G.W.; Shulman, G.I. Mitochondrial GTP regulates glucosestimulated insulin secretion. Cell Metab. 2007, 5, 253-264. [CrossRef] [PubMed]

23. Jesinkey, S.R.; Madiraju, A.K.; Alves, T.C.; Yarborough, O.H.; Cardone, R.L.; Zhao, X.; Parsaei, Y.; Nasiri, A.R.; Butrico, G.; Liu, X.; et al. Mitochondrial GTP Links Nutrient Sensing to beta Cell Health, Mitochondrial Morphology, and Insulin Secretion Independent of OxPhos. Cell Rep. 2019, 28, 759-772.e10. [CrossRef] [PubMed]

24. Metz, S.A.; Rabaglia, M.E.; Pintar, T.J. Selective inhibitors of GTP synthesis impede exocytotic insulin release from intact rat islets. J. Biol. Chem. 1992, 267, 12517-12527. [CrossRef]

25. Ottaway, J.H.; McClellan, J.A.; Saunderson, C.L. Succinic thiokinase and metabolic control. Int. J. Biochem. 1981, 13, 401-410. [CrossRef]

26. Smith, C.M.; Bryla, J.; Williamson, J.R. Regulation of mitochondrial alpha-ketoglutarate metabolism by product inhibition at alpha-ketoglutarate dehydrogenase. J. Biol. Chem. 1974, 249, 1497-1505. [CrossRef]

27. Drahota, Z.; Rauchova, H.; Mikova, M.; Kaul, P.; Bass, A. Phosphoenolpyruvate shuttle-Transport of energy from mitochondria to cytosol. FEBS Lett. 1983, 157, 347-349. [CrossRef]

28. van der Meulen, T.; Mawla, A.M.; DiGruccio, M.R.; Adams, M.W.; Nies, V.; Dolleman, S.; Liu, S.; Ackermann, A.M.; Caceres, E.; Hunter, A.E.; et al. Virgin Beta Cells Persist throughout Life at a Neogenic Niche within Pancreatic Islets. Cell Metab. 2017, 25, 911-926.e6. [CrossRef]

29. Saeedi, P.; Petersohn, I.; Salpea, P.; Malanda, B.; Karuranga, S.; Unwin, N.; Colagiuri, S.; Guariguata, L.; Motala, A.A.; Ogurtsova, K.; et al. Global and regional diabetes prevalence estimates for 2019 and projections for 2030 and 2045: Results from the International Diabetes Federation Diabetes Atlas, 9(th) edition. Diabetes Res. Clin. Pract. 2019, 157, 107843. [CrossRef]

30. Holman, R.R.; Clark, A.; Rorsman, P. beta-cell secretory dysfunction: A key cause of type 2 diabetes. Lancet. Diabetes Endocrinol. 2020, 8, 370. [CrossRef] 
31. Hudish, L.I.; Reusch, J.E.; Sussel, L. beta Cell dysfunction during progression of metabolic syndrome to type 2 diabetes. J. Clin. Investig. 2019, 129, 4001-4008. [CrossRef]

32. Magkos, F.; Hjorth, M.F.; Astrup, A. Diet and exercise in the prevention and treatment of type 2 diabetes mellitus. Nat. Rev. Endocrinol. 2020, 16, 545-555. [CrossRef]

33. Krentz, N.A.J.; Gloyn, A.L. Insights into pancreatic islet cell dysfunction from type 2 diabetes mellitus genetics. Nat. Rev. Endocrinol. 2020, 16, 202-212. [CrossRef]

34. Ashcroft, F.M.; Rorsman, P. Diabetes mellitus and the beta cell: The last ten years. Cell 2012, 148, 1160-1171. [CrossRef]

35. Bray, G.A.; Heisel, W.E.; Afshin, A.; Jensen, M.D.; Dietz, W.H.; Long, M.; Kushner, R.F.; Daniels, S.R.; Wadden, T.A.; Tsai, A.G.; et al. The Science of Obesity Management: An Endocrine Society Scientific Statement. Endocr. Rev. 2018, 39, 79-132. [CrossRef]

36. Salunkhe, V.A.; Veluthakal, R.; Kahn, S.E.; Thurmond, D.C. Novel approaches to restore beta cell function in prediabetes and type 2 diabetes. Diabetologia 2018, 61, 1895-1901. [CrossRef]

37. Gandasi, N.R.; Yin, P.; Omar-Hmeadi, M.; Ottosson Laakso, E.; Vikman, P.; Barg, S. Glucose-Dependent Granule Docking Limits Insulin Secretion and Is Decreased in Human Type 2 Diabetes. Cell Metab. 2018, 27, 470-478.e4. [CrossRef]

38. Katsarou, A.; Gudbjornsdottir, S.; Rawshani, A.; Dabelea, D.; Bonifacio, E.; Anderson, B.J.; Jacobsen, L.M.; Schatz, D.A.; Lernmark, A. Type 1 diabetes mellitus. Nat. Rev. Dis. Primers 2017, 3, 17016. [CrossRef]

39. Rojas, A.M.; Fuentes, G.; Rausell, A.; Valencia, A. The Ras protein superfamily: Evolutionary tree and role of conserved amino acids. J. Cell Biol. 2012, 196, 189-201. [CrossRef]

40. Liu, W.N.; Yan, M.; Chan, A.M. A thirty-year quest for a role of R-Ras in cancer: From an oncogene to a multitasking GTPase. Cancer Lett. 2017, 403, 59-65. [CrossRef]

41. Qu, L.; Pan, C.; He, S.M.; Lang, B.; Gao, G.D.; Wang, X.L.; Wang, Y. The Ras Superfamily of Small GTPases in Non-neoplastic Cerebral Diseases. Front. Mol. Neurosci. 2019, 12, 121. [CrossRef] [PubMed]

42. Vetter, I.R.; Wittinghofer, A. The guanine nucleotide-binding switch in three dimensions. Science 2001, 294, 1299-1304. [CrossRef] [PubMed]

43. Bourne, H.R.; Sanders, D.A.; McCormick, F. The GTPase superfamily: Conserved structure and molecular mechanism. Nature 1991, 349, 117-127. [CrossRef] [PubMed]

44. Wennerberg, K.; Rossman, K.L.; Der, C.J. The Ras superfamily at a glance. J. Cell Sci. 2005, 118, 843-846. [CrossRef]

45. Karnoub, A.E.; Weinberg, R.A. Ras oncogenes: Split personalities. Nat. Rev. Mol. Cell Biol. 2008, 9, 517-531. [CrossRef]

46. Toma-Fukai, S.; Shimizu, T. Structural Insights into the Regulation Mechanism of Small GTPases by GEFs. Molecules 2019, 24, 3308. [CrossRef]

47. Nevins, A.K.; Thurmond, D.C. Glucose regulates the cortical actin network through modulation of Cdc42 cycling to stimulate insulin secretion. Am. J. Physiol. Cell Physiol. 2003, 285, C698-C710. [CrossRef]

48. Nevins, A.K.; Thurmond, D.C. A direct interaction between Cdc42 and vesicle-associated membrane protein 2 regulates SNAREdependent insulin exocytosis. J. Biol. Chem. 2005, 280, 1944-1952. [CrossRef]

49. Nevins, A.K.; Thurmond, D.C. Caveolin-1 functions as a novel Cdc42 guanine nucleotide dissociation inhibitor in pancreatic beta-cells. J. Biol. Chem. 2006, 281, 18961-18972. [CrossRef]

50. Regazzi, R.; Kikuchi, A.; Takai, Y.; Wollheim, C.B. The small GTP-binding proteins in the cytosol of insulin-secreting cells are complexed to GDP dissociation inhibitor proteins. J. Biol. Chem. 1992, 267, 17512-17519. [CrossRef]

51. Bravo-Nuevo, A.; Sugimoto, H.; Iyer, S.; Fallon, Z.; Lucas, J.M.; Kazerounian, S.; Prendergast, G.C.; Kalluri, R.; Shapiro, N.I.; Benjamin, L.E. RhoB loss prevents streptozotocin-induced diabetes and ameliorates diabetic complications in mice. Am. J. Pathol. 2011, 178, 245-252. [CrossRef]

52. Liu, X.; Yan, F.; Yao, H.; Chang, M.; Qin, J.; Li, Y.; Wang, Y.; Pei, X. Involvement of RhoA/ROCK in insulin secretion of pancreatic beta-cells in 3D culture. Cell Tissue Res. 2014, 358, 359-369. [CrossRef]

53. Kowluru, A.; Li, G.; Rabaglia, M.E.; Segu, V.B.; Hofmann, F.; Aktories, K.; Metz, S.A. Evidence for differential roles of the Rho subfamily of GTP-binding proteins in glucose- and calcium-induced insulin secretion from pancreatic beta cells. Biochem. Pharmacol. 1997, 54, 1097-1108. [CrossRef]

54. Li, J.; Luo, R.; Kowluru, A.; Li, G. Novel regulation by Rac1 of glucose- and forskolin-induced insulin secretion in INS-1 beta-cells. Am. J. Physiol. Endocrinol. Metab. 2004, 286, E818-E827. [CrossRef]

55. Kowluru, A.; Rabaglia, M.E.; Muse, K.E.; Metz, S.A. Subcellular localization and kinetic characterization of guanine nucleotide binding proteins in normal rat and human pancreatic islets and transformed beta cells. Biochim. Biophys. Acta 1994, 1222, 348-359. [CrossRef]

56. Daniel, S.; Noda, M.; Cerione, R.A.; Sharp, G.W. A link between Cdc42 and syntaxin is involved in mastoparan-stimulated insulin release. Biochemistry 2002, 41, 9663-9671. [CrossRef]

57. Kowluru, A.; Chen, H.Q.; Tannous, M. Novel roles for the rho subfamily of GTP-binding proteins in succinate-induced insulin secretion from betaTC3 cells: Further evidence in support of the succinate mechanism of insulin release. Endocr. Res. 2003, 29, 363-376. [CrossRef]

58. Pereira-Leal, J.B.; Seabra, M.C. Evolution of the Rab family of small GTP-binding proteins. J. Mol. Biol. 2001, 313, 889-901. [CrossRef] 
59. Segev, N. Ypt and Rab GTPases: Insight into functions through novel interactions. Curr. Opin. Cell Biol. $2001,13,500-511$. [CrossRef]

60. Jackson, C.L.; Bouvet, S. Arfs at a glance. J. Cell Sci. 2014, 127, 4103-4109. [CrossRef]

61. D'Souza-Schorey, C.; Chavrier, P. ARF proteins: Roles in membrane traffic and beyond. Nat. Rev. Mol. Cell Biol. 2006, 7, 347-358. [CrossRef]

62. Benarroch, E.E. Nucleocytoplasmic transport: Mechanisms and involvement in neurodegenerative disease. Neurology 2019, 92, 757-764. [CrossRef] [PubMed]

63. Veluthakal, R.; Kaur, H.; Goalstone, M.; Kowluru, A. Dominant-negative alpha-subunit of farnesyl- and geranyltransferase inhibits glucose-stimulated, but not KCl-stimulated, insulin secretion in INS 832/13 cells. Diabetes 2007, 56, 204-210. [CrossRef]

64. Veluthakal, R.; Madathilparambil, S.V.; McDonald, P.; Olson, L.K.; Kowluru, A. Regulatory roles for Tiam1, a guanine nucleotide exchange factor for Rac1, in glucose-stimulated insulin secretion in pancreatic beta-cells. Biochem. Pharmacol. 2009, 77, 101-113. [CrossRef]

65. Wang, Z.; Oh, E.; Thurmond, D.C. Glucose-stimulated Cdc42 signaling is essential for the second phase of insulin secretion. J. Biol. Chem. 2007, 282, 9536-9546. [CrossRef]

66. Kowluru, A.; Seavey, S.E.; Li, G.; Sorenson, R.L.; Weinhaus, A.J.; Nesher, R.; Rabaglia, M.E.; Vadakekalam, J.; Metz, S.A. Glucoseand GTP-dependent stimulation of the carboxyl methylation of CDC42 in rodent and human pancreatic islets and pure beta cells. Evidence for an essential role of GTP-binding proteins in nutrient-induced insulin secretion. J. Clin. Investig. 1996, 98, 540-555. [CrossRef] [PubMed]

67. Yi, Z.; Yokota, H.; Torii, S.; Aoki, T.; Hosaka, M.; Zhao, S.; Takata, K.; Takeuchi, T.; Izumi, T. The Rab27a/granuphilin complex regulates the exocytosis of insulin-containing dense-core granules. Mol. Cell Biol. 2002, 22, 1858-1867. [CrossRef]

68. Ljubicic, S.; Bezzi, P.; Brajkovic, S.; Nesca, V.; Guay, C.; Ohbayashi, N.; Fukuda, M.; Abderrhamani, A.; Regazzi, R. The GTPase Rab37 Participates in the Control of Insulin Exocytosis. PLoS ONE 2013, 8, e68255. [CrossRef]

69. Matsunaga, K.; Taoka, M.; Isobe, T.; Izumi, T. Rab2a and Rab27a cooperatively regulate the transition from granule maturation to exocytosis through the dual effector Noc2. J. Cell Sci. 2017, 130, 541-550. [CrossRef]

70. Regazzi, R.; Vallar, L.; Ullrich, S.; Ravazzola, M.; Kikuchi, A.; Takai, Y.; Wollheim, C.B. Characterization of small-molecular-mass guanine-nucleotide-binding regulatory proteins in insulin-secreting cells and PC12 cells. Eur. J. Biochem. 1992, 208, 729-737. [CrossRef] [PubMed]

71. Shibasaki, T.; Takahashi, H.; Miki, T.; Sunaga, Y.; Matsumura, K.; Yamanaka, M.; Zhang, C.; Tamamoto, A.; Satoh, T.; Miyazaki, J.; et al. Essential role of Epac2/Rap1 signaling in regulation of insulin granule dynamics by cAMP. Proc. Natl. Acad. Sci. USA 2007, 104, 19333-19338. [CrossRef]

72. Schmidt, A.; Hall, A. Guanine nucleotide exchange factors for Rho GTPases: Turning on the switch. Genes Dev. 2002, 16, 1587-1609. [CrossRef]

73. Bernards, A.; Settleman, J. GAP control: Regulating the regulators of small GTPases. Trends Cell Biol. 2004, 14, 377-385. [CrossRef]

74. Bishop, A.L.; Hall, A. Rho GTPases and their effector proteins. Biochem. J. 2000, 348, 241-255. [CrossRef]

75. Repasky, G.A.; Chenette, E.J.; Der, C.J. Renewing the conspiracy theory debate: Does Raf function alone to mediate Ras oncogenesis? Trends Cell Biol. 2004, 14, 639-647. [CrossRef]

76. Konstantinopoulos, P.A.; Karamouzis, M.V.; Papavassiliou, A.G. Post-translational modifications and regulation of the RAS superfamily of GTPases as anticancer targets. Nat. Rev. Drug Discov. 2007, 6, 541-555. [CrossRef]

77. Wang, M.; Casey, P.J. Protein prenylation: Unique fats make their mark on biology. Nat. Rev. Mol. Cell Biol. 2016, 17, 110-122. [CrossRef]

78. Seabra, M.C.; Reiss, Y.; Casey, P.J.; Brown, M.S.; Goldstein, J.L. Protein farnesyltransferase and geranylgeranyltransferase share a common alpha subunit. Cell 1991, 65, 429-434. [CrossRef]

79. Reid, T.S.; Terry, K.L.; Casey, P.J.; Beese, L.S. Crystallographic analysis of CaaX prenyltransferases complexed with substrates defines rules of protein substrate selectivity. J. Mol. Biol. 2004, 343, 417-433. [CrossRef]

80. Goalstone, M.; Kamath, V.; Kowluru, A. Glucose activates prenyltransferases in pancreatic islet beta-cells. Biochem. Biophys. Res. Commun. 2010, 391, 895-898. [CrossRef]

81. Seabra, M.C.; Goldstein, J.L.; Sudhof, T.C.; Brown, M.S. Rab geranylgeranyl transferase. A multisubunit enzyme that prenylates GTP-binding proteins terminating in Cys-X-Cys or Cys-Cys. J. Biol. Chem. 1992, 267, 14497-14503. [CrossRef]

82. Arora, D.K.; Syed, I.; Machhadieh, B.; McKenna, C.E.; Kowluru, A. Rab-geranylgeranyl transferase regulates glucose-stimulated insulin secretion from pancreatic beta cells. Islets 2012, 4, 354-358. [CrossRef] [PubMed]

83. Wu, Y.W.; Tan, K.T.; Waldmann, H.; Goody, R.S.; Alexandrov, K. Interaction analysis of prenylated Rab GTPase with Rab escort protein and GDP dissociation inhibitor explains the need for both regulators. Proc. Natl. Acad. Sci. USA 2007, 104, 12294-12299. [CrossRef]

84. Shinde, S.R.; Maddika, S. Post translational modifications of Rab GTPases. Small GTPases 2018, 9, 49-56. [CrossRef] [PubMed]

85. Metz, S.A.; Rabaglia, M.E.; Stock, J.B.; Kowluru, A. Modulation of insulin secretion from normal rat islets by inhibitors of the post-translational modifications of GTP-binding proteins. Biochem. J. 1993, 295, 31-40. [CrossRef]

86. Li, G.; Regazzi, R.; Roche, E.; Wollheim, C.B. Blockade of mevalonate production by lovastatin attenuates bombesin and vasopressin potentiation of nutrient-induced insulin secretion in HIT-T15 cells. Probable involvement of small GTP-binding proteins. Biochem. J. 1993, 289, 379-385. [CrossRef] 
87. Amin, R.; Chen, H.Q.; Tannous, M.; Gibbs, R.; Kowluru, A. Inhibition of glucose- and calcium-induced insulin secretion from betaTC3 cells by novel inhibitors of protein isoprenylation. J. Pharm. Exp. 2002, 303, 82-88. [CrossRef]

88. Eisenberg, D.A. Cholesterol lowering in the management of coronary artery disease: The clinical implications of recent trials. Am. J. Med. 1998, 104, 2S-5S. [CrossRef]

89. Cederberg, H.; Stancakova, A.; Yaluri, N.; Modi, S.; Kuusisto, J.; Laakso, M. Increased risk of diabetes with statin treatment is associated with impaired insulin sensitivity and insulin secretion: A 6 year follow-up study of the METSIM cohort. Diabetologia 2015, 58, 1109-1117. [CrossRef]

90. Sattar, N.; Preiss, D.; Murray, H.M.; Welsh, P.; Buckley, B.M.; de Craen, A.J.; Seshasai, S.R.; McMurray, J.J.; Freeman, D.J.; Jukema, J.W.; et al. Statins and risk of incident diabetes: A collaborative meta-analysis of randomised statin trials. Lancet 2010, 375, 735-742. [CrossRef]

91. Preiss, D.; Seshasai, S.R.; Welsh, P.; Murphy, S.A.; Ho, J.E.; Waters, D.D.; DeMicco, D.A.; Barter, P.; Cannon, C.P.; Sabatine, M.S.; et al. Risk of incident diabetes with intensive-dose compared with moderate-dose statin therapy: A meta-analysis. JAMA 2011, 305, 2556-2564. [CrossRef]

92. Rajpathak, S.N.; Kumbhani, D.J.; Crandall, J.; Barzilai, N.; Alderman, M.; Ridker, P.M. Statin therapy and risk of developing type 2 diabetes: A meta-analysis. Diabetes Care 2009, 32, 1924-1929. [CrossRef]

93. Ridker, P.M.; Danielson, E.; Fonseca, F.A.; Genest, J.; Gotto, A.M., Jr.; Kastelein, J.J.; Koenig, W.; Libby, P.; Lorenzatti, A.J.; MacFadyen, J.G.; et al. Rosuvastatin to prevent vascular events in men and women with elevated C-reactive protein. N. Engl. J. Med. 2008, 359, 2195-2207. [CrossRef] [PubMed]

94. Shepherd, J.; Blauw, G.J.; Murphy, M.B.; Bollen, E.L.; Buckley, B.M.; Cobbe, S.M.; Ford, I.; Gaw, A.; Hyland, M.; Jukema, J.W.; et al. Pravastatin in elderly individuals at risk of vascular disease (PROSPER): A randomised controlled trial. Lancet 2002, 360, 1623-1630. [CrossRef]

95. Crandall, J.P.; Mather, K.; Rajpathak, S.N.; Goldberg, R.B.; Watson, K.; Foo, S.; Ratner, R.; Barrett-Connor, E.; Temprosa, M. Statin use and risk of developing diabetes: Results from the Diabetes Prevention Program. BMJ. Open Diabetes Res. Care 2017, 5, e000438. [CrossRef]

96. Kowluru, A. Small G proteins in islet beta-cell function. Endocr. Rev. 2010, 31, 52-78. [CrossRef]

97. Kowluru, A. A lack of 'glue' misplaces Rab27A to cause islet dysfunction in diabetes. J. Pathol. 2016, 238, 375-377. [CrossRef]

98. Jiang, S.; Shen, D.; Jia, W.J.; Han, X.; Shen, N.; Tao, W.; Gao, X.; Xue, B.; Li, C.J. GGPPS-mediated Rab27A geranylgeranylation regulates beta cell dysfunction during type 2 diabetes development by affecting insulin granule docked pool formation. J. Pathol. 2016, 238, 109-119. [CrossRef]

99. Wang, Z.; Thurmond, D.C. Differential phosphorylation of RhoGDI mediates the distinct cycling of Cdc42 and Rac1 to regulate second-phase insulin secretion. J. Biol. Chem. 2010, 285, 6186-6197. [CrossRef]

100. Swanston-Flatt, S.K.; Carlsson, L.; Gylfe, E. Actin filament formation in pancreatic beta-cells during glucose stimulation of insulin secretion. FEBS Lett. 1980, 117, 299-302. [CrossRef]

101. Varadi, A.; Tsuboi, T.; Rutter, G.A. Myosin Va transports dense core secretory vesicles in pancreatic MIN6 beta-cells. Mol. Biol. Cell 2005, 16, 2670-2680. [CrossRef] [PubMed]

102. Orci, L.; Gabbay, K.H.; Malaisse, W.J. Pancreatic beta-cell web: Its possible role in insulin secretion. Science 1972, 175, 1128-1130. [CrossRef] [PubMed]

103. Kepner, E.M.; Yoder, S.M.; Oh, E.; Kalwat, M.A.; Wang, Z.; Quilliam, L.A.; Thurmond, D.C. Cool-1/betaPIX functions as a guanine nucleotide exchange factor in the cycling of Cdc42 to regulate insulin secretion. Am. J. Physiol. Endocrinol. Metab. 2011, 301, E1072-E1080. [CrossRef] [PubMed]

104. Wehinger, S.; Ortiz, R.; Diaz, M.I.; Aguirre, A.; Valenzuela, M.; Llanos, P.; Mc Master, C.; Leyton, L.; Quest, A.F. Phosphorylation of caveolin-1 on tyrosine-14 induced by ROS enhances palmitate-induced death of beta-pancreatic cells. Biochim. Biophys. Acta 2015, 1852, 693-708. [CrossRef]

105. Zeng, W.; Tang, J.; Li, H.; Xu, H.; Lu, H.; Peng, H.; Lin, C.; Gao, R.; Lin, S.; Lin, K.; et al. Caveolin-1 deficiency protects pancreatic beta cells against palmitate-induced dysfunction and apoptosis. Cell Signal. 2018, 47, 65-78. [CrossRef]

106. Lillo Urzua, P.; Nunez Murillo, O.; Castro-Sepulveda, M.; Torres-Quintana, M.A.; Lladser Caldera, A.; Quest, A.F.G.; Espinoza Robles, C.; Llanos Vidal, P.; Wehinger, S. Loss of Caveolin-1 Is Associated with a Decrease in Beta Cell Death in Mice on a High Fat Diet. Int. J. Mol. Sci. 2020, 21, 5225. [CrossRef]

107. He, X.Q.; Wang, N.; Zhao, J.J.; Wang, D.; Wang, C.J.; Xie, L.; Zheng, H.Y.; Shi, S.Z.; He, J.; Zhou, J.; et al. Specific deletion of CDC42 in pancreatic beta cells attenuates glucose-induced insulin expression and secretion in mice. Mol. Cell Endocrinol. 2020, 518, 111004. [CrossRef]

108. Duan, J.; Qian, X.L.; Li, J.; Xiao, X.H.; Lu, X.T.; Lv, L.C.; Huang, Q.Y.; Ding, W.; Zhang, H.Y.; Xiong, L.X. miR-29a Negatively Affects Glucose-Stimulated Insulin Secretion and MIN6 Cell Proliferation via Cdc42/beta-Catenin Signaling. Int. J. Endocrinol. 2019, 2019, 5219782. [CrossRef]

109. Sun, Y.; Zhou, Y.; Shi, Y.; Zhang, Y.; Liu, K.; Liang, R.; Sun, P.; Chang, X.; Tang, W.; Zhang, Y.; et al. Expression of miRNA-29 in Pancreatic beta Cells Promotes Inflammation and Diabetes via TRAF3. Cell Rep. 2021, 34, 108576. [CrossRef] 
110. Ursino, G.M.; Fu, Y.; Cottle, D.L.; Mukhamedova, N.; Jones, L.K.; Low, H.; Tham, M.S.; Gan, W.J.; Mellett, N.A.; Das, P.P.; et al. ABCA12 regulates insulin secretion from beta-cells. EMBO Rep. 2020, 21, e48692. [CrossRef]

111. Veluthakal, R.; Chepurny, O.G.; Leech, C.A.; Schwede, F.; Holz, G.G.; Thurmond, D.C. Restoration of Glucose-Stimulated Cdc42-Pak1 Activation and Insulin Secretion by a Selective Epac Activator in Type 2 Diabetic Human Islets. Diabetes 2018, 67, 1999-2011. [CrossRef]

112. Asahara, S.; Shibutani, Y.; Teruyama, K.; Inoue, H.Y.; Kawada, Y.; Etoh, H.; Matsuda, T.; Kimura-Koyanagi, M.; Hashimoto, N.; Sakahara, M.; et al. Ras-related C3 botulinum toxin substrate 1 (RAC1) regulates glucose-stimulated insulin secretion via modulation of F-actin. Diabetologia 2013, 56, 1088-1097. [CrossRef]

113. Greiner, T.U.; Kesavan, G.; Stahlberg, A.; Semb, H. Rac1 regulates pancreatic islet morphogenesis. BMC Dev. Biol. 2009,9 , 2. [CrossRef]

114. Veluthakal, R.; Tunduguru, R.; Arora, D.K.; Sidarala, V.; Syeda, K.; Vlaar, C.P.; Thurmond, D.C.; Kowluru, A. VAV2, a guanine nucleotide exchange factor for Rac1, regulates glucose-stimulated insulin secretion in pancreatic beta cells. Diabetologia 2015, 58, 2573-2581. [CrossRef]

115. Gao, Y.; Dickerson, J.B.; Guo, F.; Zheng, J.; Zheng, Y. Rational design and characterization of a Rac GTPase-specific small molecule inhibitor. Proc. Natl. Acad. Sci. USA 2004, 101, 7618-7623. [CrossRef]

116. Crespo, P.; Schuebel, K.E.; Ostrom, A.A.; Gutkind, J.S.; Bustelo, X.R. Phosphotyrosine-dependent activation of Rac-1 GDP/GTP exchange by the vav proto-oncogene product. Nature 1997, 385, 169-172. [CrossRef]

117. Schuebel, K.E.; Movilla, N.; Rosa, J.L.; Bustelo, X.R. Phosphorylation-dependent and constitutive activation of Rho proteins by wild-type and oncogenic Vav-2. EMBO J. 1998, 17, 6608-6621. [CrossRef]

118. Han, J.; Das, B.; Wei, W.; Van Aelst, L.; Mosteller, R.D.; Khosravi-Far, R.; Westwick, J.K.; Der, C.J.; Broek, D. Lck regulates Vav activation of members of the Rho family of GTPases. Mol. Cell Biol. 1997, 17, 1346-1353. [CrossRef]

119. Michel, F.; Grimaud, L.; Tuosto, L.; Acuto, O. Fyn and ZAP-70 are required for Vav phosphorylation in T cells stimulated by antigen-presenting cells. J. Biol. Chem. 1998, 273, 31932-31938. [CrossRef]

120. Deckert, M.; Tartare-Deckert, S.; Couture, C.; Mustelin, T.; Altman, A. Functional and physical interactions of Syk family kinases with the Vav proto-oncogene product. Immunity 1996, 5, 591-604. [CrossRef]

121. Bustelo, X.R.; Barbacid, M. Tyrosine phosphorylation of the vav proto-oncogene product in activated B cells. Science 1992, 256, 1196-1199. [CrossRef]

122. Bustelo, X.R.; Ledbetter, J.A.; Barbacid, M. Product of vav proto-oncogene defines a new class of tyrosine protein kinase substrates. Nature 1992, 356, 68-71. [CrossRef] [PubMed]

123. Margolis, B.; Hu, P.; Katzav, S.; Li, W.; Oliver, J.M.; Ullrich, A.; Weiss, A.; Schlessinger, J. Tyrosine phosphorylation of vav proto-oncogene product containing SH2 domain and transcription factor motifs. Nature 1992, 356, 71-74. [CrossRef]

124. Yoder, S.M.; Dineen, S.L.; Wang, Z.; Thurmond, D.C. YES, a Src family kinase, is a proximal glucose-specific activator of cell division cycle control protein 42 (Cdc42) in pancreatic islet beta cells. J. Biol. Chem. 2014, 289, 11476-11487. [CrossRef] [PubMed]

125. Kowluru, A.; Veluthakal, R. Rho guanosine diphosphate-dissociation inhibitor plays a negative modulatory role in glucosestimulated insulin secretion. Diabetes 2005, 54, 3523-3529. [CrossRef]

126. Thamilselvan, V.; Kowluru, A. Paradoxical regulation of glucose-induced Rac1 activation and insulin secretion by RhoGDIbeta in pancreatic beta-cells. Small GTPases 2021, 12, 114-121. [CrossRef]

127. Hodge, R.G.; Ridley, A.J. Regulating Rho GTPases and their regulators. Nat. Rev. Mol. Cell Biol. 2016, 17, 496-510. [CrossRef] [PubMed]

128. Garcia-Mata, R.; Boulter, E.; Burridge, K. The 'invisible hand': Regulation of RHO GTPases by RHOGDIs. Nat. Rev. Mol. Cell Biol. 2011, 12, 493-504. [CrossRef] [PubMed]

129. DerMardirossian, C.; Rocklin, G.; Seo, J.Y.; Bokoch, G.M. Phosphorylation of RhoGDI by Src regulates Rho GTPase binding and cytosol-membrane cycling. Mol. Biol. Cell 2006, 17, 4760-4768. [CrossRef]

130. Dovas, A.; Choi, Y.; Yoneda, A.; Multhaupt, H.A.; Kwon, S.H.; Kang, D.; Oh, E.S.; Couchman, J.R. Serine 34 phosphorylation of rho guanine dissociation inhibitor (RhoGDIalpha) links signaling from conventional protein kinase C to RhoGTPase in cell adhesion. J. Biol. Chem. 2010, 285, 23296-23308. [CrossRef] [PubMed]

131. Sabbatini, M.E.; Williams, J.A. Cholecystokinin-mediated RhoGDI phosphorylation via PKCalpha promotes both RhoA and Rac1 signaling. PLoS ONE 2013, 8, e66029. [CrossRef]

132. DerMardirossian, C.M.; Bokoch, G.M. Phosphorylation of RhoGDI by p21-activated kinase 1. Methods Enzym. 2006, 406, 80-90. [CrossRef]

133. Fei, F.; Kweon, S.M.; Haataja, L.; De Sepulveda, P.; Groffen, J.; Heisterkamp, N. The Fer tyrosine kinase regulates interactions of Rho GDP-Dissociation Inhibitor alpha with the small GTPase Rac. BMC Biochem. 2010, 11, 48. [CrossRef]

134. Oishi, A.; Makita, N.; Sato, J.; Iiri, T. Regulation of RhoA signaling by the cAMP-dependent phosphorylation of RhoGDIalpha. J. Biol. Chem. 2012, 287, 38705-38715. [CrossRef]

135. Tkachenko, E.; Sabouri-Ghomi, M.; Pertz, O.; Kim, C.; Gutierrez, E.; Machacek, M.; Groisman, A.; Danuser, G.; Ginsberg, M.H. Protein kinase A governs a RhoA-RhoGDI protrusion-retraction pacemaker in migrating cells. Nat. Cell Biol. 2011, 13, 660-667. [CrossRef] 
136. Cho, H.J.; Kim, J.T.; Lee, S.J.; Hwang, Y.S.; Park, S.Y.; Kim, B.Y.; Yoo, J.; Hong, K.S.; Min, J.K.; Lee, C.H.; et al. Protein phosphatase 1B dephosphorylates Rho guanine nucleotide dissociation inhibitor 1 and suppresses cancer cell migration and invasion. Cancer Lett. 2018, 417, 141-151. [CrossRef]

137. Cho, H.J.; Kim, J.T.; Baek, K.E.; Kim, B.Y.; Lee, H.G. Regulation of Rho GTPases by RhoGDIs in Human Cancers. Cells 2019, 8 , 1037. [CrossRef]

138. Oude Weernink, P.A.; Lopez de Jesus, M.; Schmidt, M. Phospholipase D signaling: Orchestration by PIP2 and small GTPases. Naunyn Schmiedebergs Arch. Pharm. 2007, 374, 399-411. [CrossRef]

139. Chuang, T.H.; Bohl, B.P.; Bokoch, G.M. Biologically active lipids are regulators of Rac.GDI complexation. J. Biol. Chem. 1993, 268, 26206-26211. [CrossRef]

140. Faure, J.; Vignais, P.V.; Dagher, M.C. Phosphoinositide-dependent activation of Rho A involves partial opening of the RhoA/RhoGDI complex. Eur. J. Biochem. 1999, 262, 879-889. [CrossRef]

141. Fleming, I.N.; Elliott, C.M.; Collard, J.G.; Exton, J.H. Lysophosphatidic acid induces threonine phosphorylation of Tiam1 in Swiss 3 T3 fibroblasts via activation of protein kinase C. J. Biol. Chem. 1997, 272, 33105-33110. [CrossRef] [PubMed]

142. McDonald, P.; Veluthakal, R.; Kaur, H.; Kowluru, A. Biologically active lipids promote trafficking and membrane association of Rac1 in insulin-secreting INS 832/13 cells. Am. J. Physiol. Cell Physiol. 2007, 292, C1216-C1220. [CrossRef]

143. del Pozo, M.A.; Alderson, N.B.; Kiosses, W.B.; Chiang, H.H.; Anderson, R.G.; Schwartz, M.A. Integrins regulate Rac targeting by internalization of membrane domains. Science 2004, 303, 839-842. [CrossRef] [PubMed]

144. Del Pozo, M.A.; Kiosses, W.B.; Alderson, N.B.; Meller, N.; Hahn, K.M.; Schwartz, M.A. Integrins regulate GTP-Rac localized effector interactions through dissociation of Rho-GDI. Nat. Cell Biol. 2002, 4, 232-239. [CrossRef] [PubMed]

145. Tiedge, M.; Lortz, S.; Drinkgern, J.; Lenzen, S. Relation between antioxidant enzyme gene expression and antioxidative defense status of insulin-producing cells. Diabetes 1997, 46, 1733-1742. [CrossRef]

146. Matsuoka, T.; Kajimoto, Y.; Watada, H.; Kaneto, H.; Kishimoto, M.; Umayahara, Y.; Fujitani, Y.; Kamada, T.; Kawamori, R.; Yamasaki, Y. Glycation-dependent, reactive oxygen species-mediated suppression of the insulin gene promoter activity in HIT cells. J. Clin. Investig. 1997, 99, 144-150. [CrossRef] [PubMed]

147. Sakai, K.; Matsumoto, K.; Nishikawa, T.; Suefuji, M.; Nakamaru, K.; Hirashima, Y.; Kawashima, J.; Shirotani, T.; Ichinose, K.; Brownlee, M.; et al. Mitochondrial reactive oxygen species reduce insulin secretion by pancreatic beta-cells. Biochem. Biophys. Res. Commun. 2003, 300, 216-222. [CrossRef]

148. Kaneto, H.; Xu, G.; Song, K.H.; Suzuma, K.; Bonner-Weir, S.; Sharma, A.; Weir, G.C. Activation of the hexosamine pathway leads to deterioration of pancreatic beta-cell function through the induction of oxidative stress. J. Biol. Chem. 2001, 276, 31099-31104. [CrossRef]

149. Oliveira, H.R.; Verlengia, R.; Carvalho, C.R.; Britto, L.R.; Curi, R.; Carpinelli, A.R. Pancreatic beta-cells express phagocyte-like NAD(P)H oxidase. Diabetes 2003, 52, 1457-1463. [CrossRef]

150. Morgan, D.; Oliveira-Emilio, H.R.; Keane, D.; Hirata, A.E.; Santos da Rocha, M.; Bordin, S.; Curi, R.; Newsholme, P.; Carpinelli, A.R. Glucose, palmitate and pro-inflammatory cytokines modulate production and activity of a phagocyte-like NADPH oxidase in rat pancreatic islets and a clonal beta cell line. Diabetologia 2007, 50, 359-369. [CrossRef]

151. Rastogi, R.; Geng, X.; Li, F.; Ding, Y. NOX Activation by Subunit Interaction and Underlying Mechanisms in Disease. Front. Cell. Neurosci. 2016, 10, 301. [CrossRef]

152. Abo, A.; Pick, E.; Hall, A.; Totty, N.; Teahan, C.G.; Segal, A.W. Activation of the NADPH oxidase involves the small GTP-binding protein p21rac1. Nature 1991, 353, 668-670. [CrossRef]

153. Syed, I.; Kyathanahalli, C.N.; Jayaram, B.; Govind, S.; Rhodes, C.J.; Kowluru, R.A.; Kowluru, A. Increased phagocyte-like NADPH oxidase and ROS generation in type 2 diabetic ZDF rat and human islets: Role of Rac1-JNK1/2 signaling pathway in mitochondrial dysregulation in the diabetic islet. Diabetes 2011, 60, 2843-2852. [CrossRef]

154. Syed, I.; Kyathanahalli, C.N.; Kowluru, A. Phagocyte-like NADPH oxidase generates ROS in INS 832/13 cells and rat islets: Role of protein prenylation. Am. J. Physiol. Regul. Integr. Comp. Physiol. 2011, 300, R756-R762. [CrossRef]

155. Sidarala, V.; Veluthakal, R.; Syeda, K.; Vlaar, C.; Newsholme, P.; Kowluru, A. Phagocyte-like NADPH oxidase (Nox2) promotes activation of p38MAPK in pancreatic beta-cells under glucotoxic conditions: Evidence for a requisite role of Ras-related C3 botulinum toxin substrate 1 (Rac1). Biochem. Pharmacol. 2015, 95, 301-310. [CrossRef]

156. Veluthakal, R.; Sidarala, V.; Kowluru, A. NSC23766, a Known Inhibitor of Tiam1-Rac1 Signaling Module, Prevents the Onset of Type 1 Diabetes in the NOD Mouse Model. Cell Physiol. Biochem. 2016, 39, 760-767. [CrossRef]

157. Baidwan, S.; Chekuri, A.; Hynds, D.L.; Kowluru, A. Glucotoxicity promotes aberrant activation and mislocalization of Ras-related C3 botulinum toxin substrate 1 [Rac1] and metabolic dysfunction in pancreatic islet beta-cells: Reversal of such metabolic defects by metformin. Apoptosis 2017, 22, 1380-1393. [CrossRef]

158. Gaschet, J.; Hsu, V.W. Distribution of ARF6 between membrane and cytosol is regulated by its GTPase cycle. J. Biol. Chem. 1999, 274, 20040-20045. [CrossRef]

159. Honda, A.; Nogami, M.; Yokozeki, T.; Yamazaki, M.; Nakamura, H.; Watanabe, H.; Kawamoto, K.; Nakayama, K.; Morris, A.J.; Frohman, M.A.; et al. Phosphatidylinositol 4-phosphate 5-kinase alpha is a downstream effector of the small G protein ARF6 in membrane ruffle formation. Cell 1999, 99, 521-532. [CrossRef] 
160. Shome, K.; Nie, Y.; Romero, G. ADP-ribosylation factor proteins mediate agonist-induced activation of phospholipase D. J. Biol. Chem. 1998, 273, 30836-30841. [CrossRef]

161. Cockcroft, S.; De Matteis, M.A. Inositol lipids as spatial regulators of membrane traffic. J. Membr. Biol. 2001, 180, 187-194. [CrossRef] [PubMed]

162. Lawrence, J.T.; Birnbaum, M.J. ADP-ribosylation factor 6 regulates insulin secretion through plasma membrane phosphatidylinositol 4,5-bisphosphate. Proc. Natl. Acad. Sci. USA 2003, 100, 13320-13325. [CrossRef] [PubMed]

163. Jayaram, B.; Syed, I.; Kyathanahalli, C.N.; Rhodes, C.J.; Kowluru, A. Arf nucleotide binding site opener [ARNO] promotes sequential activation of Arf6, Cdc42 and Rac1 and insulin secretion in INS 832/13 beta-cells and rat islets. Biochem. Pharmacol. 2011, 81, 1016-1027. [CrossRef] [PubMed]

164. Aramata, S.; Han, S.I.; Yasuda, K.; Kataoka, K. Synergistic activation of the insulin gene promoter by the beta-cell enriched transcription factors MafA, Beta2, and Pdx1. Biochim. Biophys. Acta 2005, 1730, 41-46. [CrossRef] [PubMed]

165. Docherty, H.M.; Hay, C.W.; Ferguson, L.A.; Barrow, J.; Durward, E.; Docherty, K. Relative contribution of PDX-1, MafA and E47/beta2 to the regulation of the human insulin promoter. Biochem. J. 2005, 389, 813-820. [CrossRef]

166. Ma, W.N.; Park, S.Y.; Han, J.S. Role of phospholipase D1 in glucose-induced insulin secretion in pancreatic Beta cells. Exp. Mol. Med. 2010, 42, 456-464. [CrossRef]

167. Stenmark, H. Rab GTPases as coordinators of vesicle traffic. Nat. Rev. Mol. Cell Biol. 2009, 10, 513-525. [CrossRef]

168. Wandinger-Ness, A.; Zerial, M. Rab proteins and the compartmentalization of the endosomal system. Cold Spring Harb. Perspect. Biol. 2014, 6, a022616. [CrossRef]

169. Pfeffer, S.R. Rab GTPase regulation of membrane identity. Curr. Opin. Cell Biol. 2013, 25, 414-419. [CrossRef]

170. Chavrier, P.; Gorvel, J.P.; Stelzer, E.; Simons, K.; Gruenberg, J.; Zerial, M. Hypervariable C-terminal domain of rab proteins acts as a targeting signal. Nature 1991, 353, 769-772. [CrossRef]

171. Ferro-Novick, S.; Novick, P. The role of GTP-binding proteins in transport along the exocytic pathway. Annu. Rev. Cell Biol. 1993, 9, 575-599. [CrossRef]

172. Merrins, M.J.; Stuenkel, E.L. Kinetics of Rab27a-dependent actions on vesicle docking and priming in pancreatic beta-cells. J. Physiol. 2008, 586, 5367-5381. [CrossRef]

173. Haddad, E.K.; Wu, X.; Hammer, J.A., 3rd; Henkart, P.A. Defective granule exocytosis in Rab27a-deficient lymphocytes from Ashen mice. J. Cell Biol. 2001, 152, 835-842. [CrossRef]

174. Kasai, K.; Ohara-Imaizumi, M.; Takahashi, N.; Mizutani, S.; Zhao, S.; Kikuta, T.; Kasai, H.; Nagamatsu, S.; Gomi, H.; Izumi, T. Rab27a mediates the tight docking of insulin granules onto the plasma membrane during glucose stimulation. J. Clin. Investig. 2005, 115, 388-396. [CrossRef]

175. Regazzi, R.; Ravazzola, M.; Iezzi, M.; Lang, J.; Zahraoui, A.; Andereggen, E.; Morel, P.; Takai, Y.; Wollheim, C.B. Expression, localization and functional role of small GTPases of the Rab3 family in insulin-secreting cells. J. Cell Sci. 1996, 109, $2265-2273$. [CrossRef]

176. Coppola, T.; Perret-Menoud, V.; Luthi, S.; Farnsworth, C.C.; Glomset, J.A.; Regazzi, R. Disruption of Rab3-calmodulin interaction, but not other effector interactions, prevents Rab3 inhibition of exocytosis. EMBO J. 1999, 18, 5885-5891. [CrossRef]

177. Zhao, S.; Torii, S.; Yokota-Hashimoto, H.; Takeuchi, T.; Izumi, T. Involvement of Rab27b in the regulated secretion of pituitary hormones. Endocrinology 2002, 143, 1817-1824. [CrossRef]

178. Lam, A.D.; Ismail, S.; Wu, R.; Yizhar, O.; Passmore, D.R.; Ernst, S.A.; Stuenkel, E.L. Mapping dynamic protein interactions to insulin secretory granule behavior with TIRF-FRET. Biophys. J. 2010, 99, 1311-1320. [CrossRef]

179. Waselle, L.; Coppola, T.; Fukuda, M.; Iezzi, M.; El-Amraoui, A.; Petit, C.; Regazzi, R. Involvement of the Rab27 binding protein Slac2c/MyRIP in insulin exocytosis. Mol. Biol. Cell 2003, 14, 4103-4113. [CrossRef]

180. Yaekura, K.; Julyan, R.; Wicksteed, B.L.; Hays, L.B.; Alarcon, C.; Sommers, S.; Poitout, V.; Baskin, D.G.; Wang, Y.; Philipson, L.H.; et al. Insulin secretory deficiency and glucose intolerance in Rab3A null mice. J. Biol. Chem. 2003, 278, 9715-9721. [CrossRef]

181. Coppola, T.; Frantz, C.; Perret-Menoud, V.; Gattesco, S.; Hirling, H.; Regazzi, R. Pancreatic beta-cell protein granuphilin binds Rab3 and Munc-18 and controls exocytosis. Mol. Biol. Cell 2002, 13, 1906-1915. [CrossRef] [PubMed]

182. Kuroda, T.S.; Fukuda, M.; Ariga, H.; Mikoshiba, K. Synaptotagmin-like protein 5: A novel Rab27A effector with C-terminal tandem C2 domains. Biochem. Biophys. Res. Commun. 2002, 293, 899-906. [CrossRef]

183. Kuroda, T.S.; Fukuda, M.; Ariga, H.; Mikoshiba, K. The Slp homology domain of synaptotagmin-like proteins 1-4 and Slac2 functions as a novel Rab27A binding domain. J. Biol. Chem. 2002, 277, 9212-9218. [CrossRef] [PubMed]

184. Stermann, T.; Menzel, F.; Weidlich, C.; Jeruschke, K.; Weiss, J.; Altenhofen, D.; Benninghoff, T.; Pujol, A.; Bosch, F.; Rustenbeck, I.; et al. Deletion of the RabGAP TBC1D1 Leads to Enhanced Insulin Secretion and Fatty Acid Oxidation in Islets From Male Mice. Endocrinology 2018, 159, 1748-1761. [CrossRef]

185. Orci, L.; Malaisse-Lagae, F.; Ravazzola, M.; Amherdt, M.; Renold, A.E. Exocytosis-endocytosis coupling in the pancreatic beta cell. Science 1973, 181, 561-562. [CrossRef]

186. MacDonald, P.E.; Rorsman, P. The ins and outs of secretion from pancreatic beta-cells: Control of single-vesicle exo- and endocytosis. Physiology 2007, 22, 113-121. [CrossRef]

187. Cousin, M.A. Synaptic vesicle endocytosis: Calcium works overtime in the nerve terminal. Mol. Neurobiol. 2000, 22, 115-128. [CrossRef] 
188. Ryan, T.A. A pre-synaptic to-do list for coupling exocytosis to endocytosis. Curr. Opin. Cell Biol. 2006, 18, 416-421. [CrossRef]

189. Takei, K.; Yoshida, Y.; Yamada, H. Regulatory mechanisms of dynamin-dependent endocytosis. J. Biochem. 2005, 137, 243-247. [CrossRef]

190. Yamaoka, M.; Ando, T.; Terabayashi, T.; Okamoto, M.; Takei, M.; Nishioka, T.; Kaibuchi, K.; Matsunaga, K.; Ishizaki, R.; Izumi, T.; et al. PI3K regulates endocytosis after insulin secretion by mediating signaling crosstalk between Arf6 and Rab27a. J. Cell Sci. 2016, 129, 637-649. [CrossRef]

191. Paleotti, O.; Macia, E.; Luton, F.; Klein, S.; Partisani, M.; Chardin, P.; Kirchhausen, T.; Franco, M. The small G-protein Arf6GTP recruits the AP-2 adaptor complex to membranes. J. Biol. Chem. 2005, 280, 21661-21666. [CrossRef]

192. Wang, H.; Ishizaki, R.; Xu, J.; Kasai, K.; Kobayashi, E.; Gomi, H.; Izumi, T. The Rab27a effector exophilin7 promotes fusion of secretory granules that have not been docked to the plasma membrane. Mol. Biol. Cell 2013, 24, 319-330. [CrossRef]

193. Yamaoka, M.; Ishizaki, T.; Kimura, T. Interplay between Rab27a effectors in pancreatic beta-cells. World J. Diabetes 2015, 6, 508-516. [CrossRef]

194. Janoueix-Lerosey, I.; Pasheva, E.; de Tand, M.F.; Tavitian, A.; de Gunzburg, J. Identification of a specific effector of the small GTP-binding protein Rap2. Eur. J. Biochem. 1998, 252, 290-298. [CrossRef]

195. Holz, G.G. Epac: A new cAMP-binding protein in support of glucagon-like peptide-1 receptor-mediated signal transduction in the pancreatic beta-cell. Diabetes 2004, 53, 5-13. [CrossRef]

196. Kang, G.; Chepurny, O.G.; Holz, G.G. cAMP-regulated guanine nucleotide exchange factor II (Epac2) mediates Ca2+-induced Ca2+ release in INS-1 pancreatic beta-cells. J. Physiol. 2001, 536, 375-385. [CrossRef]

197. McAvoy, T.; Zhou, M.M.; Greengard, P.; Nairn, A.C. Phosphorylation of Rap1GAP, a striatally enriched protein, by protein kinase A controls Rap1 activity and dendritic spine morphology. Proc. Natl. Acad. Sci. USA 2009, 106, 3531-3536. [CrossRef]

198. Takahashi, M.; Dillon, T.J.; Liu, C.; Kariya, Y.; Wang, Z.; Stork, P.J. Protein kinase A-dependent phosphorylation of Rap1 regulates its membrane localization and cell migration. J. Biol. Chem. 2013, 288, 27712-27723. [CrossRef]

199. Leech, C.A.; Chepurny, O.G.; Holz, G.G. Epac2-dependent rap1 activation and the control of islet insulin secretion by glucagon-like peptide-1. Vitam. Horm. 2010, 84, 279-302. [CrossRef]

200. Nakazaki, M.; Crane, A.; Hu, M.; Seghers, V.; Ullrich, S.; Aguilar-Bryan, L.; Bryan, J. cAMP-activated protein kinase-independent potentiation of insulin secretion by cAMP is impaired in SUR1 null islets. Diabetes 2002, 51, 3440-3449. [CrossRef]

201. Kelly, P.; Bailey, C.L.; Fueger, P.T.; Newgard, C.B.; Casey, P.J.; Kimple, M.E. Rap1 promotes multiple pancreatic islet cell functions and signals through mammalian target of rapamycin complex 1 to enhance proliferation. J. Biol. Chem. 2010, 285, 15777-15785. [CrossRef]

202. Zhang, Y.; Parajuli, K.R.; Fava, G.E.; Gupta, R.; Xu, W.; Nguyen, L.U.; Zakaria, A.F.; Fonseca, V.A.; Wang, H.; Mauvais-Jarvis, F.; et al. GLP-1 Receptor in Pancreatic alpha-Cells Regulates Glucagon Secretion in a Glucose-Dependent Bidirectional Manner. Diabetes 2019, 68, 34-44. [CrossRef] [PubMed]

203. Richards, P.; Parker, H.E.; Adriaenssens, A.E.; Hodgson, J.M.; Cork, S.C.; Trapp, S.; Gribble, F.M.; Reimann, F. Identification and characterization of GLP-1 receptor-expressing cells using a new transgenic mouse model. Diabetes 2014, 63, 1224-1233. [CrossRef] [PubMed]

204. Moens, K.; Heimberg, H.; Flamez, D.; Huypens, P.; Quartier, E.; Ling, Z.; Pipeleers, D.; Gremlich, S.; Thorens, B.; Schuit, F. Expression and functional activity of glucagon, glucagon-like peptide I, and glucose-dependent insulinotropic peptide receptors in rat pancreatic islet cells. Diabetes 1996, 45, 257-261. [CrossRef] [PubMed]

205. Drucker, D.J. The biology of incretin hormones. Cell Metab. 2006, 3, 153-165. [CrossRef]

206. Drucker, D.J.; Nauck, M.A. The incretin system: Glucagon-like peptide-1 receptor agonists and dipeptidyl peptidase-4 inhibitors in type 2 diabetes. Lancet 2006, 368, 1696-1705. [CrossRef]

207. Gheni, G.; Ogura, M.; Iwasaki, M.; Yokoi, N.; Minami, K.; Nakayama, Y.; Harada, K.; Hastoy, B.; Wu, X.; Takahashi, H.; et al. Glutamate acts as a key signal linking glucose metabolism to incretin/cAMP action to amplify insulin secretion. Cell Rep. 2014, 9, 661-673. [CrossRef]

208. Dzhura, I.; Chepurny, O.G.; Kelley, G.G.; Leech, C.A.; Roe, M.W.; Dzhura, E.; Afshari, P.; Malik, S.; Rindler, M.J.; Xu, X.; et al. Epac2-dependent mobilization of intracellular $\mathrm{Ca}(2)+$ by glucagon-like peptide-1 receptor agonist exendin-4 is disrupted in beta-cells of phospholipase C-epsilon knockout mice. J. Physiol. 2010, 588, 4871-4889. [CrossRef]

209. Dzhura, I.; Chepurny, O.G.; Leech, C.A.; Roe, M.W.; Dzhura, E.; Xu, X.; Lu, Y.; Schwede, F.; Genieser, H.G.; Smrcka, A.V.; et al. Phospholipase C-epsilon links Epac2 activation to the potentiation of glucose-stimulated insulin secretion from mouse islets of Langerhans. Islets 2011, 3, 121-128. [CrossRef]

210. Chundru, S. Novel Regulatory Roles Of Rhog And Iqgaps In Pancreatic Islet Beta Cell Function. Ph.D. Thesis, Wayne State University, Detroit, MI, USA, 2020.

211. Mercader, J.M.; Puiggros, M.; Segre, A.V.; Planet, E.; Sorianello, E.; Sebastian, D.; Rodriguez-Cuenca, S.; Ribas, V.; Bonas-Guarch, S.; Draghici, S.; et al. Identification of novel type 2 diabetes candidate genes involved in the crosstalk between the mitochondrial and the insulin signaling systems. PLoS Genet. 2012, 8, e1003046. [CrossRef]

212. Thamilselvan, V.; Gamage, S.; Harajli, A.; Chundru, S.A.; Kowluru, A. P-Rex1 Mediates Glucose-Stimulated Rac1 Activation and Insulin Secretion in Pancreatic beta-Cells. Cell Physiol. Biochem. 2020, 54, 1218-1230. [CrossRef] 
213. Lewis, J.P.; Palmer, N.D.; Ellington, J.B.; Divers, J.; Ng, M.C.; Lu, L.; Langefeld, C.D.; Freedman, B.I.; Bowden, D.W. Analysis of candidate genes on chromosome 20q12-13.1 reveals evidence for BMI mediated association of PREX1 with type 2 diabetes in European Americans. Genomics 2010, 96, 211-219. [CrossRef]

214. Moltke, I.; Grarup, N.; Jorgensen, M.E.; Bjerregaard, P.; Treebak, J.T.; Fumagalli, M.; Korneliussen, T.S.; Andersen, M.A.; Nielsen, T.S.; Krarup, N.T.; et al. A common Greenlandic TBC1D4 variant confers muscle insulin resistance and type 2 diabetes. Nature 2014, 512, 190-193. [CrossRef]

215. Bouzakri, K.; Ribaux, P.; Tomas, A.; Parnaud, G.; Rickenbach, K.; Halban, P.A. Rab GTPase-activating protein AS160 is a major downstream effector of protein kinase B/Akt signaling in pancreatic beta-cells. Diabetes 2008, 57, 1195-1204. [CrossRef]

216. Ndiaye, F.K.; Ortalli, A.; Canouil, M.; Huyvaert, M.; Salazar-Cardozo, C.; Lecoeur, C.; Verbanck, M.; Pawlowski, V.; Boutry, R.; Durand, E.; et al. Expression and functional assessment of candidate type 2 diabetes susceptibility genes identify four new genes contributing to human insulin secretion. Mol. Metab. 2017, 6, 459-470. [CrossRef]

217. Bottcher, Y.; Schleinitz, D.; Tonjes, A.; Bluher, M.; Stumvoll, M.; Kovacs, P. R1467H variant in the rho guanine nucleotide exchange factor 11 (ARHGEF11) is associated with impaired glucose tolerance and type 2 diabetes in German Caucasians. J. Hum. Genet. 2008, 53, 365-367. [CrossRef] 